\title{
Proteomic analysis of chicken embryonic trachea and kidney tissues after infection in ovo by avian infectious bronchitis coronavirus
}

\author{
Zhongzan Cao, Zongxi Han, Yuhao Shao, Heyuan Geng, Xiangang Kong, Shengwang Liu*
}

\begin{abstract}
Background: Avian infectious bronchitis (IB) is one of the most serious diseases of economic importance in chickens; it is caused by the avian infectious coronavirus (IBV). Information remains limited about the comparative protein expression profiles of chicken embryonic tissues in response to IBV infection in ovo. In this study, we analyzed the changes of protein expression in trachea and kidney tissues from chicken embryos, following IBV infection in ovo, using two-dimensional gel electrophoresis (2-DE) coupled with matrix-assisted laser desorption/ ionization time-of-flight tandem mass spectrometry (MALDI-TOF-TOF MS).

Results: 17 differentially expressed proteins from tracheal tissues and 19 differentially expressed proteins from kidney tissues were identified. These proteins mostly related to the cytoskeleton, binding of calcium ions, the stress response, anti-oxidative, and macromolecular metabolism. Some of these altered proteins were confirmed further at the mRNA level using real-time RT-PCR. Moreover, western blotting analysis further confirmed the changes of annexin A5 and HSPB1 during IBV infection.
\end{abstract}

Conclusions: To the best of our knowledge, we have performed the first analysis of the proteomic changes in chicken embryonic trachea and kidney tissues during IBV infection in ovo. The data obtained should facilitate a better understanding of the pathogenesis of IBV infection.

\section{Background}

Avian infectious bronchitis (IB) is one of the most serious diseases of chickens. It is of economic importance in the poultry industry worldwide and is associated with respiratory disease, reduction in weight gain, poor egg production and quality, and decreased feed conversion efficiency. Its etiologic agent is the avian infectious bronchitis coronavirus (IBV), which is a Gamma coronavirus of the coronavirus genus and replicates primarily in the upper respiratory tract, kidney, and oviduct of chickens [1-3].

Knowledge of the interactions between virus and host is critical in order to understand the pathogenesis of viral infection. On the one hand, the virus usurps the biological processes of the host to evade the innate immune response of the host; on the other hand, the host mounts a variety of defensive responses against the

\footnotetext{
* Correspondence: swliu@hvri.ac.cn

State Key Laboratory of Veterinary Biotechnology, Harbin Veterinary Research Institute, the Chinese Academy of Agricultural Sciences, Harbin 150001,
} China

(C) 2011 Cao et al; licensee BioMed Central Ltd. This is an Open Access article distributed under the terms of the Creative Commons Attribution License (http://creativecommons.org/licenses/by/2.0), which permits unrestricted use, distribution, and reproduction in any medium, provided the original work is properly cited. viral infection. These virus-host interactions can cause changes in the level of expression of host genes. Alteration of gene expression in the host after infection with coronavirus $(\mathrm{CoV})$ has been investigated mainly with regard to infection with mouse hepatitis virus (MHV) and severe acute respiratory syndrome coronavirus (SARS-CoV) [4]. Limited studies have been performed to analyze host gene expression in response to IBV infection at the transcriptional level using microarray technology [5,6]. However, the altered levels of transcription do not reflect the proteomic changes that follow viral infection completely. Therefore, information about proteome changes in the host following IBV infection may be crucial in order to understand the host response to the virus and viral pathogenesis.

In the post-genome era, proteomic analysis can provide insights into the complexity of virus-host interactions. Proteomic approaches have been utilized to investigate the proteome changes in cells infected in vitro with classical swine fever virus [7], infectious bursal disease virus [8],

\section{Biomed Central}


porcine circovirus [9], and SARS-CoV [10]. Moreover, proteomic approaches have been used widely to study the mechanisms of viral infection through the comparative analysis of proteome changes in host tissue in response to infection in vivo by Marek's disease virus [11] and yellow head virus [12]. More recently, two-dimensional gel electrophoresis (2-DE) was used to compare the potential effect of several different enveloped RNA virus such as Influenza virus, respiratory syncytial virus (RSV), parainfluenza (PIV) and human metapneumovirus (hMPV) on the host cell proteome [13-16]. In addition, Edward Emmott revealed changes in the cytoplasmic, nuclear and nucleolar proteomes in Vero cells and DF-1 cells infected with IBV using Stable Isotope Labeling by Amino acids in Cell culture (SILAC) technique $[17,18]$. Study on identification of the incorporated host proteins in purified IBV particles has also been reported [19]. Whereas, no studies have been reported to date of the comparative protein expression profiles of chicken embryonic tissues in response to IBV infection either in vitro or in vivo.

In the present study, we made use of two-dimensional gel electrophoresis (2-DE) coupled with matrix-assisted laser desorption/ionization time-of-flight tandem mass spectrometry (MALDI-TOF-TOF MS) analysis to observe changes of protein expression in the trachea and kidney tissues of chicken embryos after IBV infection in ovo. The results may provide the clues that will increase our understanding of the IBV-host interaction and the pathogenesis of IBV.

\section{Results}

\section{IBV infection in chicken embryos}

Seventy-two hours after inoculation with the IBV vaccine $\mathrm{H}_{120}$ strain, all IBV-infected chicken embryos showed obvious signs of IBV infection, such as dwarfing, stunting, curling, and embryonic death. In contrast, the mockinfected chicken embryos were healthy (Figure 1). Analysis of allantoic fluids from embryos in the IBV-infected group by EM showed the presence of virus particles with typical Coronavirus morphology; these were not detected in the mock-infected group (data not shown). Using RTPCR amplification of the majority of the $\mathrm{N}$ gene and parts of the 3'-UTR, the expected 1600bp band was observed only in samples from the IBV-infected group; samples from the mock-infected group were negative, as described previously [20] (data not shown). These results indicated that chicken embryos in the IBV-infected group were infected successfully by IBV.

\section{Comparison of differential protein expression in trachea and kidney tissues between IBV-infected and mock- infected chicken embryos}

In order to investigate the proteomic changes in trachea and kidney tissues in response to IBV infection, 2-DE analysis was carried out of the total proteins from trachea and kidney tissues of IBV-infected and mockinfected chicken embryos. Figure 2 shows representative gels of tracheal tissue proteins resolved on $13 \mathrm{~cm} \mathrm{pH} \mathrm{4-}$ 7 IPG strips followed by SDS-PAGE: $1035 \pm 47$ and $1030 \pm 61$ protein spots were detected in 2 -DE gels from the IBV-infected group and mock-infected group, respectively. Figure 3 shows representative gels of tracheal tissue proteins resolved on $13 \mathrm{~cm}$ linear $\mathrm{pH}$ 3-10 IPG strips followed by SDS-PAGE: $1248 \pm 28$ and 1060 \pm 18 protein spots were detected in $2-\mathrm{DE}$ gels from the IBV-infected group and mock-infected group, respectively. Thirty protein spots showed statistically significant changes in expression in chicken embryonic tracheal tissues from the IBV-infected group compared with those of the mock-infected group using Image Master Software analysis. Figure 4 shows representative gels of kidney tissue proteins resolved on $13 \mathrm{~cm}$ linear pH 3-10 IPG strips followed by SDS-PAGE: $1125 \pm 32$ and $1074 \pm 116$ protein spots were detected in 2 -DE gels from the IBV-infected group and mock-infected group, respectively. Quantitative analysis revealed that 23 protein spots showed statistically significant changes in expression in chicken embryonic kidney tissues from the IBV-infected group compared with those from the mock-infected group.

A magnified comparison of eleven differentially expressed protein spots, representing ANXA1, HSPB1, MYLPF, TRIM27.2, EXFABP, ANXA5, PRDX1, TPM1, ENO1, ANXA2 and CALB, is shown in Figure 5.

\section{Identification of differentially expressed proteins by MALDI-TOF-TOF MS and MS/MS analysis}

All protein spots that showed differential changes in expression of 1.5 fold or greater $(\mathrm{p}<0.05)$ were analyzed by MALDI-TOF-TOF MS and MS/MS analysis. The PMF and MS/MS spectral data were searched against the NCBInr database using MASCOT. As shown in Table 1, 17 proteins from tracheal tissues were identified successfully. Proteins increased in abundance included extracellular fatty acid-binding protein (EXFABP), a putative uncharacterized protein (TRIM27.2), ubiquitin carboxylterminal esterase L1 (UCHL1), replication factor C (activator 1) 2, a cholinergic receptor (nicotinic, gamma polypeptide precursor), ARP2 actin-related protein 2 homolog, ovotransferrin, a second cholinergic receptor (nicotinic, alpha 7 precursor), chaperonin containing TCP1 subunit 8 , and ovoinhibitor precursor. Proteins decreased in abundance included myosin light chain 3 (skeletal muscle isoform), myosin light chain 1 (skeletal muscle isoform), myosin light chain type 2 (MYLPF), heat shock $27 \mathrm{kDa}$ protein (HSPB1), creatine kinase $M$ chain, annexin A1 (ANXA1) and Rho GDP dissociation inhibitor (GDI) alpha. Table 2 shows the 19 proteins identified from 


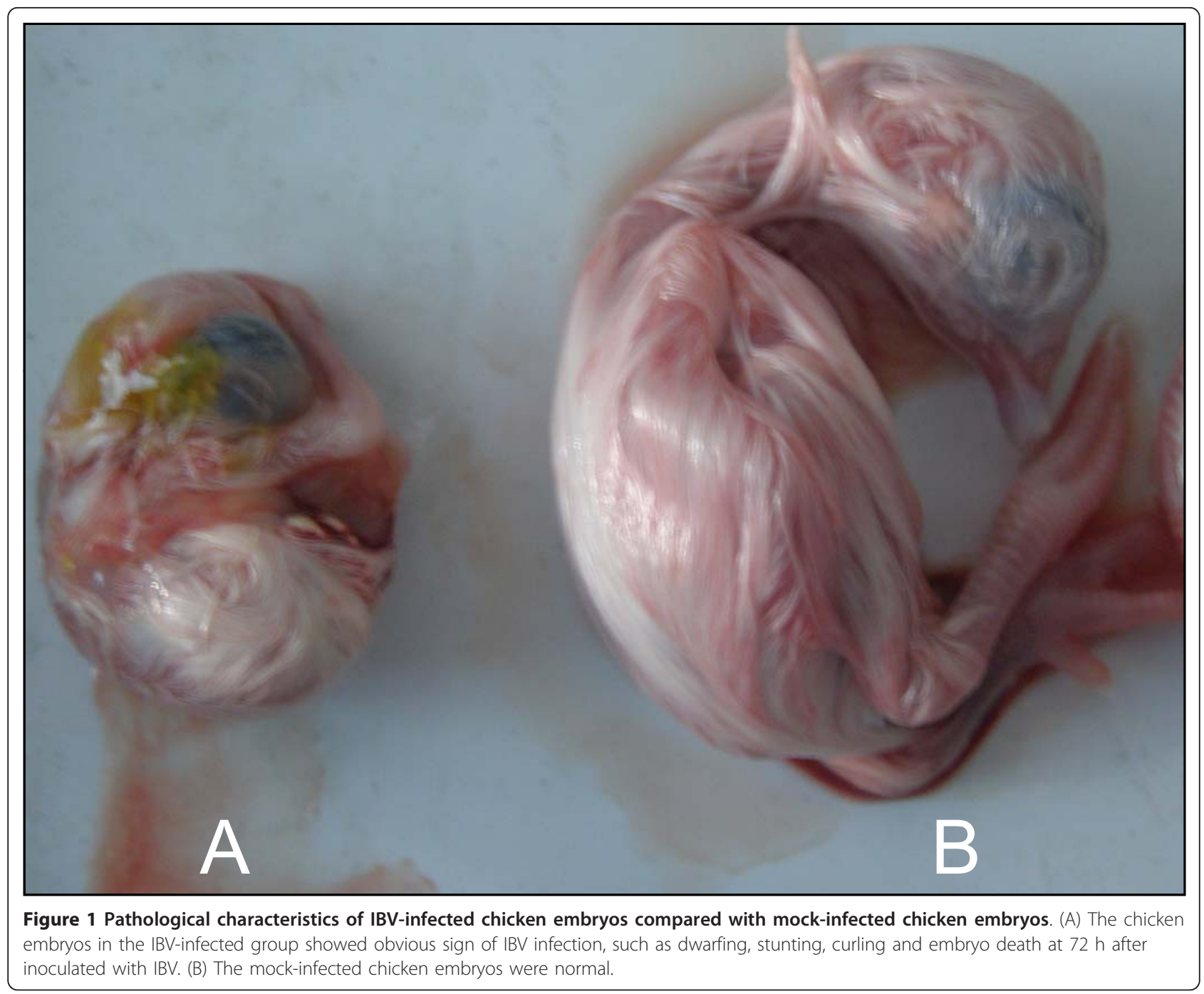

kidney tissues. Of these, proteins increased in abundance included carbonic anhydrase II, glutathione S-transferase 2 , a protein of the sulfotransferase family, L-lactate dehydrogenase B, L-3-hydroxyacyl-coenzyme A dehydrogenase, cystathionase, enolase 1 (ENO1), CNDP dipeptidase 2, phosphoenolpyruvate carboxykinase, and calbindin- $\mathrm{D}_{28} \mathrm{k}$ (CALB1). Proteins decreased in abundance included tropomyosin beta chain (TPM2), tropomyosin 1 alpha (TPM1), annexin A5 (ANXA5), peroxiredoxin-1 (PRDX1), carbonyl reductase 1, NADP-dependent isocitrate dehydrogenase, annexin A6 (ANXA6), and MHC class I antigen. Annexin A2 (ANXA2) was identified in two spots (Figure 4, spots 1 and 12). The abundance of spot 1 was increased, but spot 12 was decreased. Calbindin- $\mathrm{D}_{28} \mathrm{k}$ and MHC class I antigen were detectable only in the IBVinfected group because the spots in the mock-infected group were too weak.

According to the UniProtKB and the Gene Ontology databases, the identified proteins could be classified into several functional categories, including cytoskeletal proteins, calcium ion-binding proteins, proteins related to macromolecule metabolism, anti-oxidative proteins, protein and nucleotide processing, the ubiquitin-proteasome pathway, immune response and antigen processing and presentation, response to stress, signal transduction, and metal ion binding. Detailed information about the PMF and MS/MS search results is listed in Additional file 1, Additional file 2, Additional file 3 and Additional file 4 .

\section{Analysis of identified proteins at the transcriptional level} Alterations in expression of a protein may be due to a change in its mRNA level. In order to confirm the results of the proteomics analysis at the mRNA level, the transcriptional alterations in five selected proteins from tracheal tissues and six selected proteins from kidney tissues were measured by real-time RT-PCR. Figure 6 shows normalized fold changes of the mRNA of these 


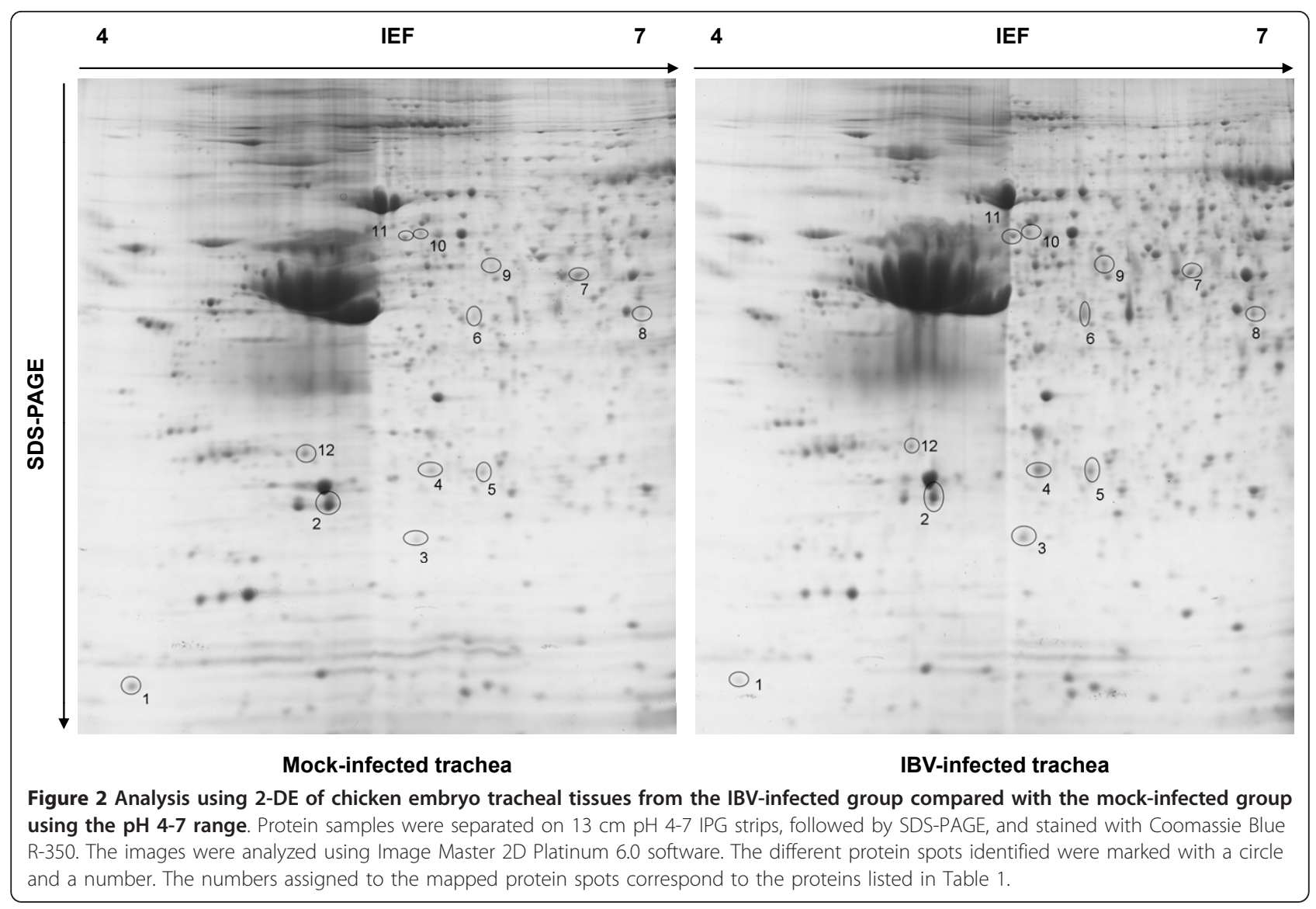

genes in chicken embryos of the IBV-infected group and in mock-infected chicken embryos. In tracheal tissues, the mRNA level of ANXA1, HSPB1, and MYLPF was decreased in IBV-infected chicken embryos by 0.32 , $0.39,0.31$ fold, respectively, compared with mockinfected chicken embryos. The mRNA level of TRIM27.2 and EXFABP was increased by 1.28 and 1.52 fold, respectively, and the trends of the changes in their mRNA levels were similar to the patterns of change in their corresponding proteins on 2-DE gels. For kidney tissues, the trends of change in the mRNA levels of ANXA5, PRDX1, TPM1, and ENO1 were consistent with the 2-DE results. Interestingly, ANXA2 had results that contrasted with those of the 2-DE methods. CALB1 was found to show no obvious difference between the IBV-infected group and the mock-infected group.

\section{Protein validation by Western blotting}

To further confirm the protein alterations during IBV infection identified by 2-DE and MALDI-TOF/TOF mass spectrometry, the protein annexin A5 and HSPB1 were selected for Western blotting analysis and GAPDH as loading control. As shown in Figure 7, the abundance of annexin A5 was decreased in kidney tissues of IBV- infected group compared to mock-infected group, and the abundance of HSPB1 was decreased in tracheal tissues of IBV-infected group compared to mock-infected group. The results were consistent with the expression change shown by the 2-DE analysis.

\section{Discussion}

Virus infection and the host response involve a complex interplay of host and viral networks in which many viruses attempt to subvert host cell processes to increase the efficiency of virus infection, and likewise the host employs a number of responses to generate an anti-viral state [17]. Coronavirus (CoV) infection can cause alterations in the transcription and translation patterns, cell cycle, cytoskeleton, and apoptosis pathways of the host cell [4]. The trachea and kidney are the primary target organs of IBV, investigation of the proteomic changes in these tissues after IBV infection in ovo helps to elucidate the IBV-host interaction and the pathogenic mechanisms of IBV. In this study, proteomic methods coupled with real-time RT-PCR and western blotting were applied to identify the differentially expressed proteins in trachea and kidney tissues of IBV-infected and mockinfected chicken embryos. We now attempt to interpret 


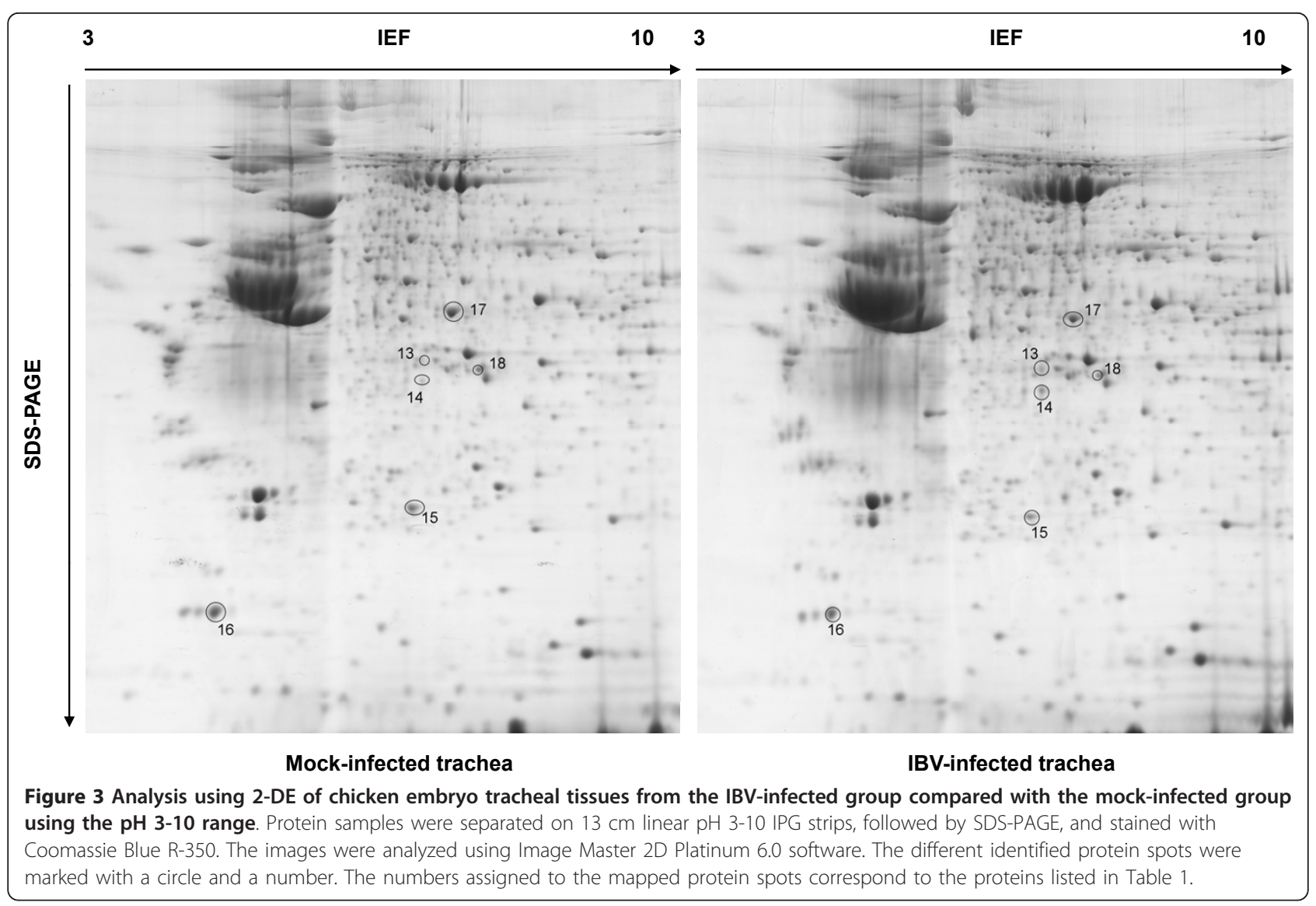

the possible functional roles of some proteins identified during IBV infection in ovo.

In our study, one of the major findings was that the abundances of some cytoskeletal proteins including TPM1 and MYLPF were decreased in the IBV-infected group. Their alterations were also confirmed at the mRNA level by real-time RT-PCR. Tropomyosin belongs to the family of actin-binding proteins that serves important functions in microfilament stabilization, regulation of microfilament branching, actin polymerization, and intracellular transport [21]. Myosins are a large superfamily of motor proteins that are involved in movement along actin filaments, the development of myriad cells, targeted organelle transport, endocytosis, chemotaxis, cytokinesis, and signal transduction [22]. Similar result was observed in the IBV-infected cells by using SILAC technique $[17,18]$. Changes in cytoskeleton proteins have been reported in other virus infection in vitro, including infectious bursal virus [8], H9N2 avian influenza virus [23], respiratory syncytial virus [16], and SARS-associated CoV [10]. During the process of virus infection, particularly in the stages of virus entry and virus budding, the cytoskeletal network of the host cell is involved in the transport of viral components within the cell. Moreover, some viral proteins can interact with the cytoskeletal transport machinery, such as actin-binding proteins or actin, and induce rearrangements of cytoskeletal filaments so that they can utilize them as tracks or push them aside when they represent barriers [24]. In the present study, several actin-binding proteins, including TPM1 and MYLPF, their abundance were found to be decreased in the IBV-infected group, which suggests that IBV may also manipulate the host cytoskeletal network for its own infectious processes and replication.

It is well known that $\mathrm{Ca}^{2+}$ is one of the most universal and versatile signaling molecule, and involved in almost every aspect of cellular processes. The $\mathrm{Ca}^{2+}$ plays important roles in virus entry, viral gene expression, posttranslational processing of viral proteins, and the maturation and release of virions. Viruses can utilize host cellular $\mathrm{Ca}^{2+}$ and $\mathrm{Ca}^{2+}$-binding proteins to create a tailored cellular environment that meets their own demands for the replication cycle [25]. In this study, the level of expression of some calcium ion-binding proteins, including Calbindin- $\mathrm{D}_{28} \mathrm{k}$, annexin $\mathrm{A} 1$, annexin $\mathrm{A} 2$, annexin $\mathrm{A} 5$, and annexin A6 were altered after IBV infection in ovo. Calbindin- $\mathrm{D}_{28} \mathrm{k}$ is a cytosolic calcium-binding protein that facilitates $1,25(\mathrm{OH})_{2} \mathrm{D}_{3}$ dependent transcellular calcium transport. It was also observed to protect 


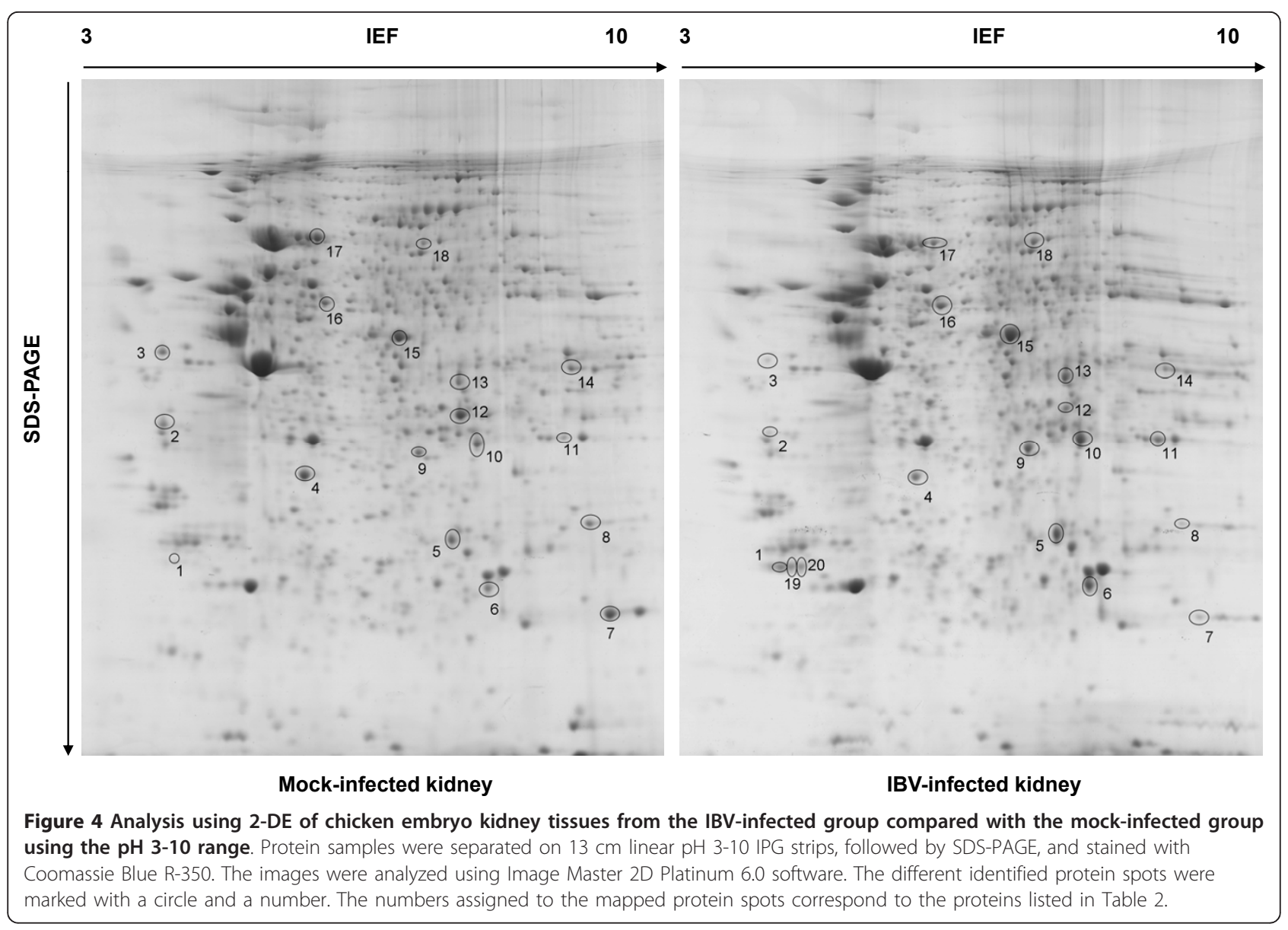

against apoptosis in different cell types [26,27]. In this study, its abundance was remarkably increased in the IBV-infected group, which suggests that IBV might specially utilize calbindin- $\mathrm{D}_{28} \mathrm{k}$ to perturb the cellular $\mathrm{Ca}^{2+}$ homeostasis and $\mathrm{Ca}^{2+}$-signaling network for its own benefit. Annexins are a family of structurally related proteins that bind phospholipids and cellular membranes in a calcium-dependent manner [28]. Annexin A2 has been shown to take part in the initiation of membrane fusion in exocytosis, membrane trafficking, regulation of cell proliferation and apoptosis, and stabilization of membrane-associated protein complexes with the actin cytoskeleton $[29,30]$. In addition, Annexin A2 can promote the entry of human immunodeficiency virus (HIV) into monocyte-derived macrophages [29], and it was also identified to be a potential receptor for respiratory syncytial virus on human epithelial cells [31]. Annexin A2 on the lung epithelial cell surface was recognized by SARS-associated CoV spike domain 2 antibodies and identified as an autoantigen [32]. Annexin A5 was found to be involved in cytomegalovirus infection [33] and influenza virus infection [34]. Annexin A1 plays a critical role in a variety of cellular processes such as proliferation, differentiation, and apoptosis [35]. Its abundance was shown to be increased in HepaRG cells infected with hepatitis B virus (HBV) in vitro [36], and fish cells infected in vitro with infectious pancreatic necrosis virus [37]. Changes in the abundance of some annexins family proteins also were identified in IBV-infected DF-1 cells by Edward Emmott and coworkers [18]. In current study, the abundance of annexin A1, annexin A5, and annexin A6 were all decreased in the IBV-infected group. For annexin A2, two spots were identified in kidney tissue, the abundance of one spot was increased, and another spot was decreased. Of these, the decrease of annexin A5 was confirmed by real-time RT-PCR and western blotting analysis. These data suggested that they may play special roles during IBV infection or replication.

Remarkably, several stress response and anti-oxidative proteins were found to be changed significantly in the present study. HSPB1 is an important small heat shock protein (HSP) that is synthesized in response to a wide variety of stressful stimuli, including viral infection. It has diverse functions including chaperone activity, Factin modulation, signal transduction, resistance to 


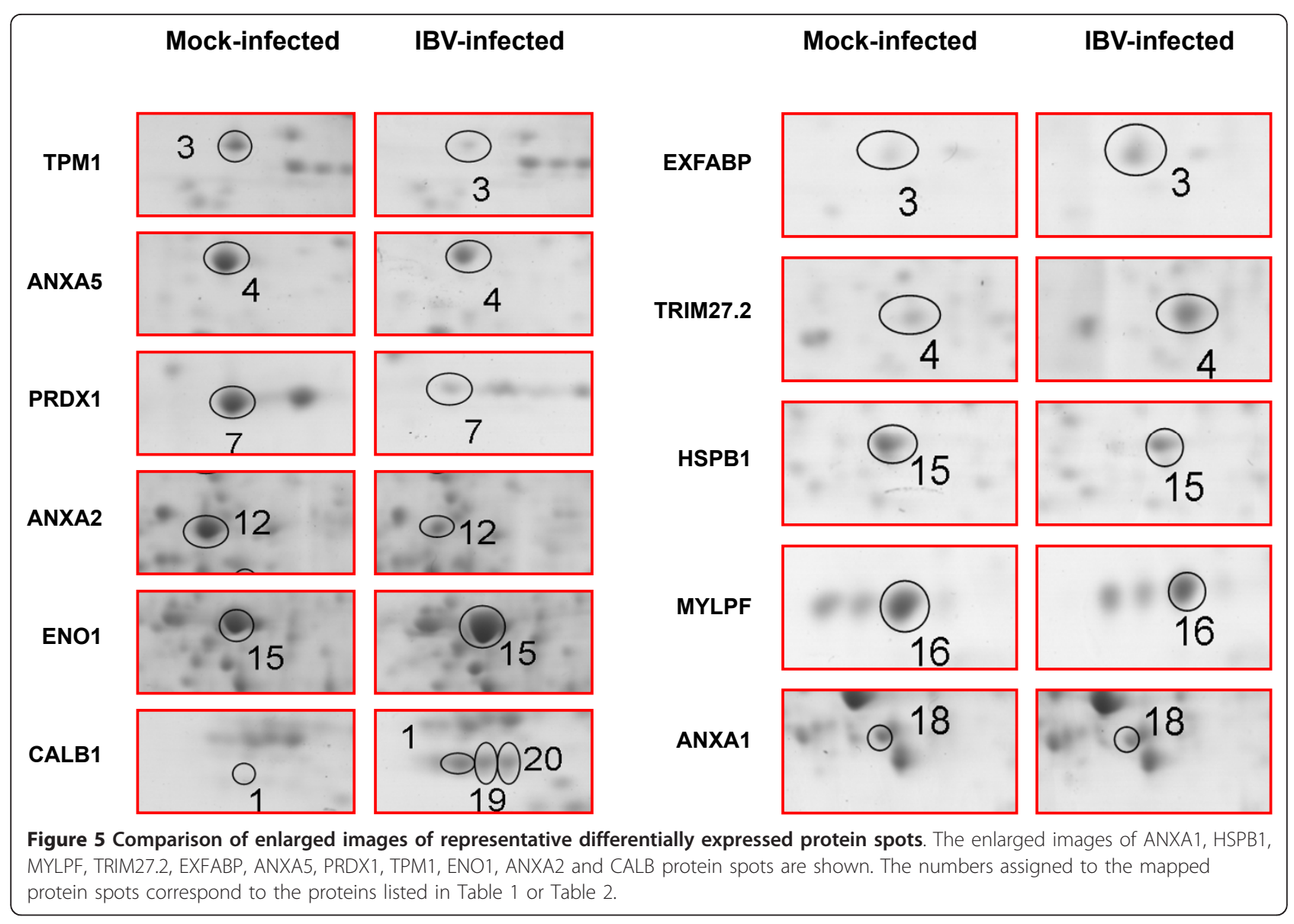

oxidant stress, regulation of translational initiation, and modulation of inflammation, inhibition of apoptosis, and cell differentiation and proliferation [38,39]. Enhanced levels of HSPB1 and/or phosphoHSPB1 can promote nuclear transport of adenovirus in MK2-deficient cells [40]. The abundance of HSPB1 has found to be increased in cells infected in vitro with $\mathrm{H} 9 \mathrm{~N} 2$ avian influenza virus [23], African swine fever virus [41], and infectious bursal disease virus [8]. In contrast, its abundance was found to be decreased in cells infected in vitro with mumps virus [42] and porcine circovirus type 2 [9], which suggests that HSPB1 may play different roles in different virus infections or different stages of infection. PRDX1 is the most ubiquitously expressed member of the peroxiredoxin family, which is involved in anti-oxidative processes, cell differentiation and proliferation, immune responses, regulation of apoptosis, and as a molecular chaperone [43]. PRDX1 participates in the apoptosis signal-regulating kinase 1 (ASK1)mediated signaling pathway, and plays an inhibitory role in ASK1-induced apoptosis [44]. Its abundance was shown to be decreased in peripheral blood mononuclear cell (PBMC) following CSFV infection in vivo [45]. In our study, the abundance of HSPB1 and PRDX1 were shown to be decreased after IBV infection in ovo by 2DE and real-time RT-PCR methods. Furthermore, the change of HSPB1 expression was confirmed by western blotting. This alteration may allow the infected cells to be eliminated by apoptosis, or serve as a form of host defense against IBV infection.

Viral replication requires energy and macromolecular precursors derived from the metabolic network of the host. In the present results obtained using 2-DE, the abundance of some proteins which are associated with carbohydrate, amino acid, and lipid metabolic processes were found to be differentially changed. Enolase- 1 is a key enzyme of glycolysis and gluconeogenesis that catalyzes the dehydration of 2-phosphoglycerate to phosphoenolpyruvate [46]. Its abundance was found to be changed in many virus infections, such as white spot syndrome virus [47], and porcine reproductive and respiratory syndrome virus [48]. Phosphoenolpyruvate carboxykinase is another gluconeogenic enzyme; it catalyzes the GTP-driven conversion of oxaloacetate to phosphoenolpyruvate [49]. Increased expression of proteins related to energy metabolism was also found in HIV-infected peripheral blood mononuclear cells [50], chicken spleen tissue infected with Marek's disease virus 
Table 1 List of differentially expressed protein spots in tracheal tissues identified by MALDI-TOF-TOF MS and MS/MS analysis

\begin{tabular}{|c|c|c|c|c|c|c|c|c|c|c|c|}
\hline \multirow[t]{2}{*}{ Spot $^{\mathrm{a}}$} & \multirow[t]{2}{*}{$\begin{array}{l}\text { Accession } \\
\text { Number }^{b}\end{array}$} & \multirow[t]{2}{*}{ Protein Description } & \multirow{2}{*}{$\begin{array}{l}\mathrm{Mr} \\
(\mathrm{KDa}) / \\
\mathrm{pl}\end{array}$} & \multirow[t]{2}{*}{ Score } & \multirow[t]{2}{*}{$\begin{array}{l}\text { Coverage } \\
(\%)^{d}\end{array}$} & \multicolumn{2}{|c|}{$\begin{array}{l}\text { Normalized spot } \\
\text { volume (vol\%) }\end{array}$} & \multirow[t]{2}{*}{$p$} & \multirow{2}{*}{$\begin{array}{l}\text { Ratio } \\
\text { (infected/ } \\
\text { mock- } \\
\text { infected) }\end{array}$} & \multirow[t]{2}{*}{ Protein functions } & \multirow[t]{2}{*}{$\begin{array}{l}\text { Other viruses } \\
\text { found } \text { in }^{f}\end{array}$} \\
\hline & & & & & & $\begin{array}{l}\text { Mock- } \\
\text { infected }\end{array}$ & $\begin{array}{l}\text { IBV- } \\
\text { infected }\end{array}$ & & & & \\
\hline \multicolumn{12}{|c|}{ Cytoskeletal and calcium ion-binding proteins } \\
\hline 1 & $\begin{array}{l}\text { gil } \\
55584150\end{array}$ & $\begin{array}{l}\text { Myosin light chain 3, skeletal } \\
\text { muscle isoform [Gallus gallus] }\end{array}$ & $\begin{array}{l}16.7 / \\
4.52\end{array}$ & $81^{c}$ & 38 & $\begin{array}{l}0.1007 \pm \\
0.0245\end{array}$ & $\begin{array}{l}0.0452 \pm \\
0.0118\end{array}$ & 0.024 & 0.45 & Motor activity. Calcium ion binding. & IAV, RSV, CVB3 \\
\hline 2 & gi|212347 & $\begin{array}{l}\text { Myosin light chain 1, skeletal } \\
\text { muscle isoform [Gallus gallus] }\end{array}$ & $\begin{array}{l}19.5 / \\
4.96\end{array}$ & 192 & 53 & $\begin{array}{l}0.6040 \pm \\
0.0519\end{array}$ & $\begin{array}{l}0.3576 \pm \\
0.0656\end{array}$ & 0.007 & 0.59 & Motor activity. Calcium ion binding. & \\
\hline 16 & $\begin{array}{l}\text { gi| } \\
50403707\end{array}$ & $\begin{array}{l}\text { myosin light chain type } 2 \\
\text { (LC2f) [Gallus gallus] }\end{array}$ & $\begin{array}{l}18.9 / \\
4.77\end{array}$ & 220 & 33 & $\begin{array}{l}0.4716 \pm \\
0.0545\end{array}$ & $\begin{array}{l}0.2784 \pm \\
0.0257\end{array}$ & 0.005 & 0.59 & Motor activity. Calcium ion binding. & VHSV \\
\hline 18 & $\begin{array}{l}\text { gil } \\
46195459\end{array}$ & annexin A1 [Gallus gallus] & $\begin{array}{l}38.5 / \\
7.05\end{array}$ & $142^{c}$ & 39 & $\begin{array}{l}0.1277 \pm \\
0.0106\end{array}$ & $\begin{array}{l}0.0596 \pm \\
0.0118\end{array}$ & 0.002 & 0.47 & $\begin{array}{l}\text { Calcium/phospholipid-binding protein. Promotes } \\
\text { membrane fusion. Involved in exocytosis. Regulates } \\
\text { phospholipase A2 activity. Inflammation response }\end{array}$ & $\begin{array}{l}\text { CSFV, PRRSV, HBV, } \\
\text { RSV, VHSV, WNV }\end{array}$ \\
\hline \multicolumn{12}{|c|}{ Carbohydrate and lipid metabolic proteins } \\
\hline 3 & $\begin{array}{l}\text { gil } \\
20178282\end{array}$ & $\begin{array}{l}\text { Extracellular fatty acid-binding } \\
\text { protein [Gallus gallus] }\end{array}$ & $\begin{array}{l}20.1 / \\
5.56\end{array}$ & 361 & 46 & $\begin{array}{l}0.0495 \pm \\
0.0094\end{array}$ & $\begin{array}{l}0.1058 \pm \\
0.0221\end{array}$ & 0.015 & 2.14 & $\begin{array}{l}\text { Fatty acid binding and transporting. Inflammatory } \\
\text { response. }\end{array}$ & \\
\hline 17 & $\begin{array}{l}\text { gi| } \\
45382875\end{array}$ & $\begin{array}{l}\text { Creatine kinase M chain } \\
\text { [Gallus gallus] }\end{array}$ & $\begin{array}{l}43.3 / \\
6.5\end{array}$ & 287 & 50 & $\begin{array}{l}0.5632 \pm \\
0.0122\end{array}$ & $\begin{array}{l}0.2546 \pm \\
0.0488\end{array}$ & $<.001$ & 0.45 & $\begin{array}{l}\text { Nucleotide binding. Catalytic activity. Creatine kinase } \\
\text { activity }\end{array}$ & HBV, VHSV \\
\hline \multicolumn{12}{|c|}{$\underline{\text { Stress response protein }}$} \\
\hline 15 & $\begin{array}{l}\text { gil } \\
45384222\end{array}$ & $\begin{array}{l}\text { Heat shock } 27 \mathrm{kDa} \text { protein } \\
\text { [Gallus gallus] }\end{array}$ & $\begin{array}{l}21.7 / \\
5.77\end{array}$ & 166 & 61 & $\begin{array}{l}0.2906 \pm \\
0.0637\end{array}$ & $\begin{array}{l}0.1531 \pm \\
0.0432\end{array}$ & 0.036 & 0.53 & Response to stress. Anti-apoptosis & $\begin{array}{l}\text { CSFV, PRRSV, } \\
\text { PCV2, ASFV, AIV, } \\
\text { MDV, IBDV, REOV, } \\
1 \text { AV, CVB3 }\end{array}$ \\
\hline \multicolumn{12}{|c|}{ Protein and nucleotide processing } \\
\hline 5 & $\begin{array}{l}\text { gi| } \\
122692295\end{array}$ & $\begin{array}{l}\text { ubiquitin carboxyl-terminal } \\
\text { esterase L1 [Gallus gallus] }\end{array}$ & $\begin{array}{l}25.1 / \\
5.74\end{array}$ & 142 & 31 & $\begin{array}{l}0.0563 \pm \\
0.0019\end{array}$ & $\begin{array}{l}0.0980 \pm \\
0.0071\end{array}$ & 0.001 & 1.74 & Ubiquitin binding, Protein deubiquitination & DHBV, IBDV \\
\hline 6 & $\begin{array}{l}\text { gil } \\
45382983\end{array}$ & $\begin{array}{l}\text { replication factor C (activator } \\
\text { 1) 2,40 kDa [Gallus gallus] }\end{array}$ & $\begin{array}{l}40.1 / \\
5.68\end{array}$ & $87^{c}$ & 45 & $\begin{array}{l}0.0542 \pm \\
0.0128\end{array}$ & $\begin{array}{l}0.1931 \pm \\
0.0297\end{array}$ & 0.002 & 3.56 & Nucleotide binding. ATP binding & \\
\hline 10 & $\begin{array}{l}\text { gil } \\
52138673\end{array}$ & $\begin{array}{l}\text { chaperonin containing TCP1, } \\
\text { subunit } 8 \text { (theta) [Gallus } \\
\text { gallus] }\end{array}$ & $\begin{array}{l}59.5 / \\
5.35\end{array}$ & 300 & 37 & $\begin{array}{l}0.0403 \pm \\
0.0031\end{array}$ & $\begin{array}{l}0.0760 \pm \\
0.0047\end{array}$ & 0.001 & 1.89 & Protein binding. Nucleotide binding & $\begin{array}{l}\text { PRRSV, EV71, } \\
\text { HPV8, IAV }\end{array}$ \\
\hline 11 & $\begin{array}{l}\text { gil } \\
52138673\end{array}$ & $\begin{array}{l}\text { chaperonin containing TCP1, } \\
\text { subunit } 8 \text { (theta) [Gallus } \\
\text { gallus] }\end{array}$ & $\begin{array}{l}59.5 / \\
5.35\end{array}$ & 356 & 47 & $\begin{array}{l}0.0559 \pm \\
0.0021\end{array}$ & $\begin{array}{l}0.1228 \pm \\
0.0375\end{array}$ & 0.037 & 2.20 & Protein binding. Nucleotide binding & $\begin{array}{l}\text { PRRSV, EV71, } \\
\text { HPV8, IAV }\end{array}$ \\
\hline 4 & $\begin{array}{l}\text { gi| } \\
150247116\end{array}$ & $\begin{array}{l}\text { Putative uncharacterized } \\
\text { protein TRIM27.2 (Tripartite } \\
\text { motif-containing) [Gallus } \\
\text { gallus] }\end{array}$ & $\begin{array}{l}27.21 \\
5.25\end{array}$ & $289^{c}$ & 46 & $\begin{array}{l}0.0792 \pm \\
0.0116\end{array}$ & $\begin{array}{l}0.2098 \pm \\
0.0196\end{array}$ & 0.001 & 2.65 & Protein binding. Metal ion binding & \\
\hline 9 & $\begin{array}{l}\text { gil } \\
45383758\end{array}$ & $\begin{array}{l}\text { cholinergic receptor, nicotinic, } \\
\text { alpha } 7 \text { precursor [Gallus } \\
\text { gallus] }\end{array}$ & $\begin{array}{l}56.9 / \\
5.47\end{array}$ & $159^{c}$ & 29 & $\begin{array}{l}0.0323 \pm \\
0.0055\end{array}$ & $\begin{array}{l}0.0723 \pm \\
0.0182\end{array}$ & 0.022 & 2.24 & $\begin{array}{l}\text { Acetylcholine receptor activity. Activation of MAPK } \\
\text { activity. Cellular calcium ion homeostasis }\end{array}$ & \\
\hline
\end{tabular}


Table 1 List of differentially expressed protein spots in tracheal tissues identified by MALDI-TOF-TOF MS and MS/MS analysis (Continued)

\begin{tabular}{|c|c|c|c|c|c|c|c|c|c|c|c|}
\hline 7 & $\begin{array}{l}\text { gil } \\
71896049\end{array}$ & $\begin{array}{l}\text { cholinergic receptor, nicotinic, } \\
\text { gamma polypeptide } \\
\text { precursor [Gallus gallus] }\end{array}$ & $\begin{array}{ll}59.6 / \\
5.53\end{array}$ & $142^{c}$ & 26 & $\begin{array}{l}0.0701 \pm \\
0.0132\end{array}$ & $\begin{array}{l}0.1207 \pm \\
0.0039\end{array}$ & 0.003 & 1.72 & $\begin{array}{l}\text { Nicotinic acetylcholine-activated cation-selective } \\
\text { channel activity. Ion channel activity }\end{array}$ & \\
\hline $8-1$ & $\begin{array}{l}\text { gi| } \\
45382569\end{array}$ & $\begin{array}{l}\text { ARP2 actin-related protein } 2 \\
\text { homolog [Gallus gallus] }\end{array}$ & $\begin{array}{l}45.0 / \\
6.3\end{array}$ & $157^{c}$ & 51 & $\begin{array}{l}0.0747 \pm \\
0.0027\end{array}$ & $\begin{array}{l}0.1336 \pm \\
0.0187\end{array}$ & 0.006 & 1.79 & ATP binding. Actin binding. Protein binding & \\
\hline 13 & $\begin{array}{l}\text { gi| } \\
71895337\end{array}$ & $\begin{array}{l}\text { ovoinhibitor precursor [Gallus } \\
\text { gallus] }\end{array}$ & $\begin{array}{l}54.4 / \\
6.16\end{array}$ & $128^{c}$ & 39 & $\begin{array}{l}0.0334 \pm \\
0.0139\end{array}$ & $\begin{array}{l}0.1046 \pm \\
0.0364\end{array}$ & 0.034 & 3.13 & $\begin{array}{l}\text { Serine-type endopeptidase inhibitor activity. } \\
\text { Peptidase inhibitor activity. }\end{array}$ & \\
\hline 14 & $\begin{array}{l}\text { gi| } \\
71895337\end{array}$ & $\begin{array}{l}\text { ovoinhibitor precursor [Gallus } \\
\text { gallus] }\end{array}$ & $\begin{array}{l}54.4 / \\
6.16\end{array}$ & 291 & 40 & $\begin{array}{l}0.0545 \pm \\
0.0228\end{array}$ & $\begin{array}{l}0.1074 \pm \\
0.0119\end{array}$ & 0.029 & 1.97 & $\begin{array}{l}\text { Serine-type endopeptidase inhibitor activity. } \\
\text { Peptidase inhibitor activity. }\end{array}$ & \\
\hline \multicolumn{12}{|c|}{ Signal transduction } \\
\hline 12 & $\begin{array}{l}\text { gi| } \\
124249432\end{array}$ & $\begin{array}{l}\text { Rho GDP dissociation } \\
\text { inhibitor (GDI) alpha [Gallus } \\
\text { gallus] }\end{array}$ & $\begin{array}{l}23.3 / \\
5.22\end{array}$ & 264 & 60 & $\begin{array}{l}0.1091 \pm \\
0.0127\end{array}$ & $\begin{array}{l}0.0619 \pm \\
0.0131\end{array}$ & 0.011 & 0.57 & $\begin{array}{l}\text { Rho GDP-dissociation inhibitor activity. Signal } \\
\text { transduction }\end{array}$ & $\begin{array}{l}\text { CSFV, RSV, WSSV, } \\
\text { YHV, IBDV }\end{array}$ \\
\hline \multicolumn{12}{|c|}{ Metal ion binding } \\
\hline $8-2$ & $\begin{array}{l}\text { gi| } \\
17942831\end{array}$ & $\begin{array}{l}\text { Chain A, Ovotransferrin, C- } \\
\text { Terminal Lobe, Apo Form }\end{array}$ & $\begin{array}{l}39.4 / \\
6.31\end{array}$ & $93^{c}$ & 49 & $\begin{array}{l}0.0747 \pm \\
0.0027\end{array}$ & $\begin{array}{l}0.1336 \pm \\
0.0187\end{array}$ & 0.006 & 1.79 & Metal ion binding. Iron ion transport & \\
\hline
\end{tabular}

a) Spot ID: is the unique number which refers to the labels in Figure 2 and Figure 3.

b) Accession Number: gi number in NCBI.

c) Score: Protein score based only on MS spectra by MALDI-TOF, other spots based on combined MS and MS/MS spectra from MALDI-TOF-TOF identification, a protein score greater than 83 is significant in this study $(\mathrm{p}<0.05)$.

d) Coverage (\%): Percentage of identified protein sequences covered by matched peptides.

e) Values are presented as mean $\pm S D . n=3 ;$ vol \% was defined as the ratio of the intensity volume of each spot to that of all spots calculated by the software. The SD represents standard deviation of the vol \% in three biological replicates.

f) IAV, Influenza A virus; RSV, Human respiratory syncytial virus; CVB3, coxsackievirus B3; VHSV, Viral haemorrhagic septicemia virus; CSFV, classical swine fever virus; PRRSV, Porcine reproductive and respiratory syndrome virus; PCV2, Porcine circovirus type 2; ASFV, African swine fever virus; HBV, Hepatitis B virus; AIV, Avian influenza virus; EV71, Enterovirus 71; MDV, Marek's disease virus; WSSV, White spot syndrome virus; DHBV, Duck heptatitis B virus; YHV, yellow head virus; HPV8, Human papillomavirus type 8; REOV, Reovirus; IBDV, Infectious bursal disease virus. 
Table 2 List of differentially expressed protein spots in kidney tissues identified by MALDI-TOF-TOF MS and MS/MS analysis

\begin{tabular}{|c|c|c|c|c|c|c|c|c|c|c|c|}
\hline \multirow[t]{2}{*}{ Spot $^{\mathrm{a}}$} & \multirow[t]{2}{*}{$\begin{array}{l}\text { Accession } \\
\text { Number }^{\mathrm{b}}\end{array}$} & \multirow[t]{2}{*}{ Protein Description } & \multirow{2}{*}{$\begin{array}{l}\mathrm{Mr} \\
(\mathrm{KDa}) / \\
p \mathrm{I}\end{array}$} & \multirow[t]{2}{*}{ Score } & \multirow[t]{2}{*}{$\begin{array}{l}\text { Coverage } \\
(\%)^{d}\end{array}$} & \multicolumn{2}{|c|}{$\begin{array}{l}\text { Normalized spot } \\
\text { volume (vol\%) }\end{array}$} & \multirow[t]{2}{*}{$p$} & \multirow{2}{*}{$\begin{array}{l}\text { Ratio } \\
\text { (infected/ } \\
\text { mock- } \\
\text { infected) }\end{array}$} & \multirow[t]{2}{*}{ Protein function } & \multirow[t]{2}{*}{ Other viruses found in ${ }^{f}$} \\
\hline & & & & & & $\begin{array}{l}\text { Mock- } \\
\text { infected }\end{array}$ & $\begin{array}{l}\text { IBV- } \\
\text { infected }\end{array}$ & & & & \\
\hline \multicolumn{12}{|c|}{ Cytoskeletal proteins } \\
\hline 2 & gi|515694 & $\begin{array}{l}\text { Tropomyosin beta chain [Gallus } \\
\text { gallus] }\end{array}$ & $\begin{array}{l}28.5 / \\
4.65\end{array}$ & 123 & 31 & $\begin{array}{l}0.2134 \pm \\
0.0092\end{array}$ & $\begin{array}{l}0.0524 \pm \\
0.0162\end{array}$ & $\begin{array}{l}< \\
0.001\end{array}$ & 0.25 & Actin binding & HBV, HCV, WSSV \\
\hline 3 & $\begin{array}{l}\text { gil } \\
45382323\end{array}$ & $\begin{array}{l}\text { Tropomyosin } 1 \text { alpha [Gallus } \\
\text { gallus] }\end{array}$ & $\begin{array}{l}32.9 / \\
4.73\end{array}$ & 307 & 57 & $\begin{array}{l}0.1907 \pm \\
0.0219\end{array}$ & $\begin{array}{l}0.0474 \pm \\
0.0188\end{array}$ & 0.001 & 0.25 & Actin binding & $\begin{array}{l}\text { PRRSV, RSV, HPV8, VHSV, } \\
\text { CVB3 }\end{array}$ \\
\hline \multicolumn{12}{|c|}{ Calcium ion-binding proteins } \\
\hline 1 & $\begin{array}{l}\text { gi| } \\
45382533\end{array}$ & annexin A2 [Gallus gallus] & $\begin{array}{l}38.7 / \\
6.92\end{array}$ & 389 & 67 & $\begin{array}{l}0.0388 \pm \\
0.0177\end{array}$ & $\begin{array}{l}0.2153 \pm \\
0.0838\end{array}$ & 0.023 & 5.55 & $\begin{array}{l}\text { Phospholipase inhibitor activity. Calcium } \\
\text { ion binding }\end{array}$ & $\begin{array}{l}\text { CSFV, PRRSV, HBV, HIV, } \\
\text { DHBV, WNV }\end{array}$ \\
\hline 12 & $\begin{array}{l}\text { gi } \\
45382533\end{array}$ & annexin A2 [Gallus gallus] & $\begin{array}{l}38.6 / \\
6.92\end{array}$ & 505 & 69 & $\begin{array}{l}0.5186 \pm \\
0.1260\end{array}$ & $\begin{array}{l}0.1549 \pm \\
0.0474\end{array}$ & 0.009 & 0.3 & $\begin{array}{l}\text { Phospholipase inhibitor activity. Calcium } \\
\text { ion binding }\end{array}$ & \\
\hline 4 & $\begin{array}{l}\text { gi| } \\
71895873\end{array}$ & annexin 5 [Gallus gallus] & $\begin{array}{l}36.2 / \\
5.6\end{array}$ & 402 & 71 & $\begin{array}{l}0.4276 \pm \\
0.0516\end{array}$ & $\begin{array}{l}0.1898 \pm \\
0.0334\end{array}$ & 0.003 & 0.44 & $\begin{array}{l}\text { Calcium ion binding. Calcium- } \\
\text { dependent phospholipid binding }\end{array}$ & $\begin{array}{l}\text { PRRSV, DV, DHBV, HBV, } \\
\text { VHSV }\end{array}$ \\
\hline 17 & $\begin{array}{l}\text { gil } \\
50982399\end{array}$ & annexin A6 [Gallus gallus] & $\begin{array}{l}75.2 / \\
5.57\end{array}$ & 441 & 49 & $\begin{array}{l}0.4317 \pm \\
0.0389\end{array}$ & $\begin{array}{l}0.1653 \pm \\
0.0107\end{array}$ & $\begin{array}{l}< \\
0.001\end{array}$ & 0.38 & $\begin{array}{l}\text { Calcium ion binding. Calcium- } \\
\text { dependent phospholipid binding }\end{array}$ & \\
\hline 19 & $\begin{array}{l}\text { gi| } \\
45382893\end{array}$ & calbindin 1, 28 kDa [Gallus gallus] & $\begin{array}{l}30.4 / \\
4.72\end{array}$ & 212 & 60 & N/A & $\begin{array}{l}0.1485 \pm \\
0.0614\end{array}$ & 0.014 & N/A & Calcium ion binding. Vitamin D binding & \\
\hline 20-1 & $\begin{array}{l}\text { gi| } \\
45382893\end{array}$ & calbindin 1, 28 kDa [Gallus gallus] & $\begin{array}{l}30.2 / \\
4.72\end{array}$ & 285 & 50 & N/A & $\begin{array}{l}0.1527 \pm \\
0.0545\end{array}$ & 0.008 & N/A & Calcium ion binding. Vitamin D binding & \\
\hline \multicolumn{12}{|c|}{ Carbohydrate and lipid metabolic proteins } \\
\hline 5 & $\begin{array}{l}\text { gi| } \\
46048696\end{array}$ & $\begin{array}{l}\text { carbonic anhydrase II [Gallus } \\
\text { gallus] }\end{array}$ & $\begin{array}{l}29.4 / \\
6.56\end{array}$ & 354 & 75 & $\begin{array}{l}0.2622 \pm \\
0.0554\end{array}$ & $\begin{array}{l}0.4806 \pm \\
0.0850\end{array}$ & 0.020 & 1.83 & $\begin{array}{l}\text { Morphogenesis of an epithelium. One- } \\
\text { carbon metabolic process }\end{array}$ & \\
\hline 8 & $\begin{array}{l}\text { gi| } \\
71895267\end{array}$ & $\begin{array}{l}\text { carbonyl reductase } 1 \text { [Gallus } \\
\text { gallus] }\end{array}$ & $\begin{array}{l}30.5 / \\
8.5\end{array}$ & 357 & 82 & $\begin{array}{l}0.1847 \pm \\
0.0160\end{array}$ & $\begin{array}{l}0.0909 \pm \\
0.0220\end{array}$ & 0.004 & 0.49 & Catalytic activity. Oxidoreductase activity & VHSV \\
\hline 10 & $\begin{array}{l}\text { gi } \\
45383766\end{array}$ & $\begin{array}{l}\text { L-lactate dehydrogenase B [Gallus } \\
\text { gallus] }\end{array}$ & $\begin{array}{l}36.3 / \\
7.07\end{array}$ & 306 & 40 & $\begin{array}{l}0.3102 \pm \\
0.0260\end{array}$ & $\begin{array}{l}0.6368 \pm \\
0.1152\end{array}$ & 0.009 & 2.05 & $\begin{array}{l}\text { Glycolysis. Oxidoreductase activity, } \\
\text { acting on the CH-OH group of donors, } \\
\text { NAD or NADP as acceptor }\end{array}$ & $\begin{array}{l}\text { PRRSV, HBV, HIV, IBDV, } \\
\text { REOV }\end{array}$ \\
\hline 11 & $\begin{array}{l}\text { gil } \\
118090053\end{array}$ & $\begin{array}{l}\text { similar to L-3-hydroxyacyl- } \\
\text { Coenzyme A dehydrogenase, } \\
\text { short chain [Gallus gallus] }\end{array}$ & $\begin{array}{l}34.4 / \\
8.68\end{array}$ & 135 & 39 & $\begin{array}{l}0.0814 \pm \\
0.0048\end{array}$ & $\begin{array}{l}0.2186 \pm \\
0.0820\end{array}$ & 0.044 & 2.69 & $\begin{array}{l}\text { Catalytic activity. Oxidoreductase } \\
\text { activity. Fatty acid metabolic process }\end{array}$ & \\
\hline 14 & $\begin{array}{l}\text { gil } \\
118093509\end{array}$ & $\begin{array}{l}\text { PREDICTED: similar to cytosolic } \\
\text { NADP-dependent isocitrate } \\
\text { dehydrogenase [Gallus gallus] }\end{array}$ & $\begin{array}{l}46.6 / \\
8.02\end{array}$ & 412 & 47 & $\begin{array}{l}0.2077 \pm \\
0.0198\end{array}$ & $\begin{array}{l}0.0942 \pm \\
0.0092\end{array}$ & 0.001 & 0.45 & Oxidoreductase activity & PRRSV, PCV2, HBV, RSV \\
\hline 15 & $\begin{array}{l}\text { gil } \\
46048768\end{array}$ & enolase 1 [Gallus gallus] & $\begin{array}{l}47.3 / \\
6.17\end{array}$ & 387 & 57 & $\begin{array}{l}0.5718 \pm \\
0.1537\end{array}$ & $\begin{array}{l}1.2489 \pm \\
0.0439\end{array}$ & 0.002 & 2.18 & Glycolysis & $\begin{array}{l}\text { PRRSV, PCV2, WSSV, HSV-1, } \\
\text { RSV, DHBV, HIV, IBDV, HBV, } \\
\text { VHSV, WNV, SARS-CoV }\end{array}$ \\
\hline 18 & $\begin{array}{l}\text { gil } \\
110591367\end{array}$ & $\begin{array}{l}\text { Chain A, The Structure Of } \\
\text { Chicken Mitochondrial Pepck }\end{array}$ & $\begin{array}{l}67.3 / \\
6.55\end{array}$ & 441 & 49 & $\begin{array}{l}0.0866 \pm \\
0.0138\end{array}$ & $\begin{array}{l}0.1704 \pm \\
0.0253\end{array}$ & 0.007 & 1.97 & Gluconeogenesis & HBV, SARS-COV \\
\hline
\end{tabular}


Table 2 List of differentially expressed protein spots in kidney tissues identified by MALDI-TOF-TOF MS and MS/MS analysis (Continued)

\begin{tabular}{|c|c|c|c|c|c|c|c|c|c|c|c|}
\hline \multicolumn{12}{|c|}{ Amino acid metabolic proteins } \\
\hline 6 & gi|2981970 & $\begin{array}{l}\text { glutathione S-transferases } 2 \\
\text { [Gallus gallus] }\end{array}$ & $\begin{array}{l}25.8 / \\
7.0\end{array}$ & 437 & 68 & $\begin{array}{l}0.1877 \pm \\
0.0201\end{array}$ & $\begin{array}{l}0.4192 \pm \\
0.0767\end{array}$ & 0.007 & 2.23 & Amino acid metabolic process & HBV \\
\hline 13 & $\begin{array}{l}\text { gil } \\
118094764\end{array}$ & $\begin{array}{l}\text { PREDICTED: similar to } \\
\text { cystathionase [Gallus gallus] }\end{array}$ & $\begin{array}{l}43.9 / \\
6.86\end{array}$ & 399 & 35 & $\begin{array}{l}0.1704 \pm \\
0.0390\end{array}$ & $\begin{array}{l}0.3164 \pm \\
0.0547\end{array}$ & 0.02 & 1.86 & Cysteine biosynthetic process & \\
\hline \multicolumn{12}{|c|}{ Antioxidative stress proteins } \\
\hline 7 & $\begin{array}{l}\text { gi| } \\
50751518\end{array}$ & $\begin{array}{l}\text { PREDICTED: similar to } \\
\text { peroxiredoxin-1 [Gallus gallus] }\end{array}$ & $\begin{array}{l}22.3 / \\
8.24\end{array}$ & 252 & 42 & $\begin{array}{l}0.5474 \pm \\
0.0371\end{array}$ & $\begin{array}{l}0.1253 \pm \\
0.0600\end{array}$ & $\begin{array}{l}< \\
0.001\end{array}$ & 0.23 & $\begin{array}{l}\text { Response to oxidative stress. Removal } \\
\text { of superoxide radicals. Regulation of } \\
\text { stress-activated MAPK cascade }\end{array}$ & $\begin{array}{l}\text { CSFV, PRRSV, RSV, SARS- } \\
\text { COV, HBV, IAV }\end{array}$ \\
\hline \multicolumn{12}{|c|}{ Protein processing } \\
\hline 16 & $\begin{array}{l}\text { gi| } \\
57530409\end{array}$ & $\begin{array}{l}\text { CNDP dipeptidase } 2 \text { [Gallus } \\
\text { gallus] }\end{array}$ & $\begin{array}{l}53.1 / \\
5.71\end{array}$ & 403 & 52 & $\begin{array}{l}0.1743 \pm \\
0.0319\end{array}$ & $\begin{array}{l}0.3196 \pm \\
0.0759\end{array}$ & 0.038 & 1.83 & Proteolysis & \\
\hline 9 & $\begin{array}{l}\text { gi| } \\
45382969\end{array}$ & $\begin{array}{l}\text { sulfotransferase family, cytosolic, } \\
\text { 1C, member } 3 \text { [Gallus gallus] }\end{array}$ & $\begin{array}{l}36.2 / \\
6.68\end{array}$ & 245 & 47 & $\begin{array}{l}0.1481 \pm \\
0.0412\end{array}$ & $\begin{array}{l}0.2923 \pm \\
0.0578\end{array}$ & 0.024 & 1.97 & Sulfotransferase activity. Detoxicating & \\
\hline \multicolumn{12}{|c|}{ Immune response proteins } \\
\hline $20-2$ & $\begin{array}{l}\text { gi| } \\
54606655\end{array}$ & $\begin{array}{l}\text { MHC class I antigen [Gallus } \\
\text { gallus] }\end{array}$ & $\begin{array}{l}37.6 / \\
6.09\end{array}$ & $385^{c}$ & 71 & N/A & $\begin{array}{l}0.1527 \pm \\
0.0545\end{array}$ & 0.008 & N/A & $\begin{array}{l}\text { Immune response. Antigen processing } \\
\text { and presentation }\end{array}$ & BVDV \\
\hline
\end{tabular}

a) Spot ID: is the unique number which refers to the labels in Figure 4 .

b) Accession Number: gi number in NCBI.

c) Score: Protein score based only on MS spectra by MALDI-TOF, other spots based on combined MS and MS/MS spectra from MALDI-TOF-TOF identification, a protein score greater than 83 is significant in this study $(\mathrm{P}<0.05)$.

d) Sequence coverage (\%): Percentage of identified protein sequences covered by matched peptides.

e) Values are presented as mean $\pm S D . n=3$; vol \% was defined as the ratio of the intensity volume of each spot to that of all spots calculated by the software. The SD represents standard deviation of the vol \% in three biological replicates.

$\mathrm{N} / \mathrm{A}$ : A indicates the spot was detectable on one of the gels, $\mathrm{N}$ indicates the spot was too weak to detect on one of the gels.

f) HCV, Hepatitis C virus; VSV, Vesicular stomatitis virus; HSV-1, Herpes simplex virus type-1; DV, Dengue virus; HIV, Human immunodeficiency virus; SARS-CoV, Severe acute respiratory syndrome -associated

coronavirus; VHSV, Viral haemorrhagic septicemia virus; WNV, West Nile virus; BVDV, Bovine viral diarrhea virus. 


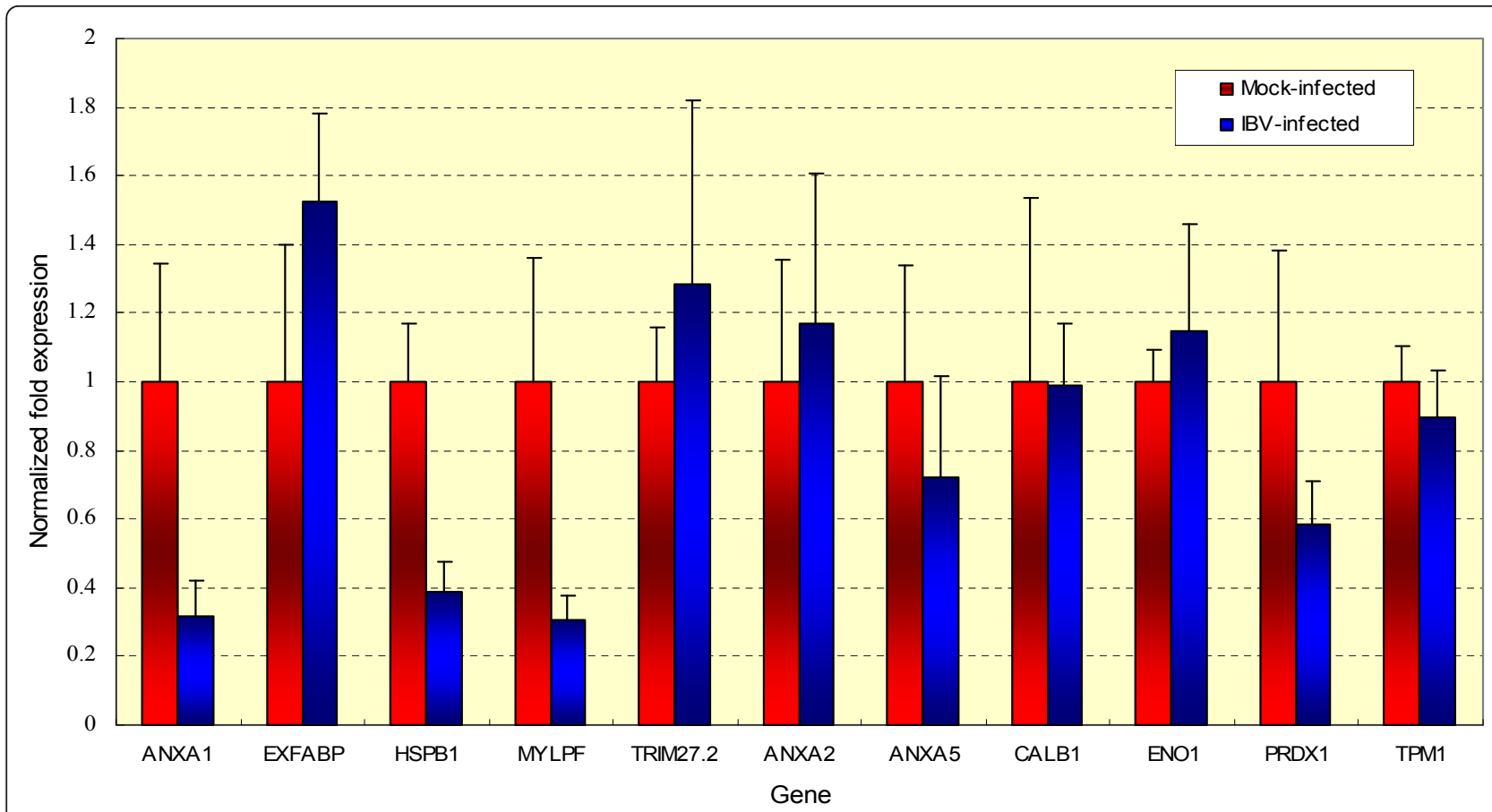

Figure 6 Transcript alteration of eleven selected genes in chicken embryo tissues from the IBV-infected group compared with the mock-infected group. Total RNA extracted from tracheal or kidney tissues was measured by real-time RT-PCR analysis; relative expression levels were calculated according to the $2^{-\triangle \triangle C T}$ method, using GAPDH as an internal reference gene and the mock-infected group as calibrator (relative expression $=1$ ). Error bar shows the standard deviation. Gene symbols indicating different genes refer to Table 1 or Table 2.

[11], and human cytomegalovirus-infected human fibroblasts [51]. The abundance of L-lactate dehydrogenase B also found to be increased in IBV-infected cells by SILAC technique $[17,18]$. Up-regulation of proteins related to energy metabolism may meet the requirement for a large burst of oxygen and energy during rapid virus replication, and also may result from an attempt by the host to keep up with the energy demand during viral infection. Ex-FABP is $21 \mathrm{kDa}$ lipocalin that is involved in fatty acid transport and lipid metabolism. It may play an important role in the protection of cells against the toxic effects of the accumulation of fatty acids. The expression of Ex-FABP is enhanced greatly in response to inflammatory stimuli and other stress conditions $[52,53]$. In this study, its abundance was significantly increased in tracheal tissue of IBV-infected chicken embryos, suggesting may serve as a response to the inflammation induced by IBV infection in ovo.

The abundance of several proteins which involved in the immune response and antigen processing and presentation were also observed to be changed in this study. TRIM protein is a member of a protein family that is based on a conserved domain architecture characterized by a RING finger domain, one or two B-box domains, a coiled-coil domain and a variable C-terminus. TRIM proteins are involved in a variety of cellular processes that include signal transduction, transcriptional regulation, cell proliferation, apoptosis, and immunity [54]. Many TRIM proteins, such as TRIM5 $\alpha$, TRIM11, TRIM22, TRIM28, TRIM31, and TRIM62, have been found to display antiviral activity or to be involved in processes associated with innate immunity [55-57]. An extended gene map revealed that TRIM27.2 lies within a sub-region of the chicken MHC-B that affects infectious disease [58]. The major histocompatibility complex (MHC) plays an important role in regulation of the immune response and antigen presentation. The transcription levels of the MHC class II-associated invariant chain and MHC class II $\beta$ chain were observed to be increased in tracheal epithelial layers of chickens three days after infection with an attenuated IBV-Massachusetts strain [6]. In current study, the abundance of TRIM27.2 and MHC class I antigen were increased remarkably following IBV infection in ovo. According to our knowledge, TRIM27.2 has never been found in other virus analysis so far. This change might be induced specially by IBV infection.

\section{Conclusions}

In summary, we have performed the first analysis of the proteomic changes in chicken embryonic trachea and kidney tissues during IBV infection in ovo. We identified a series of proteins that are related mainly to the 


\section{Mock-infected group IBV-infected group}

\section{ANXA5}

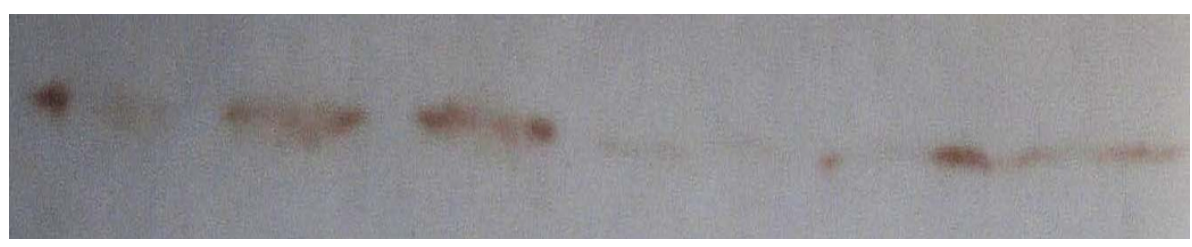

\section{GAPDH}

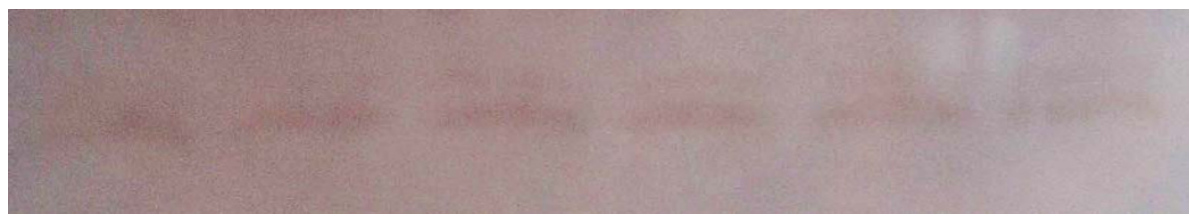

HSPB1

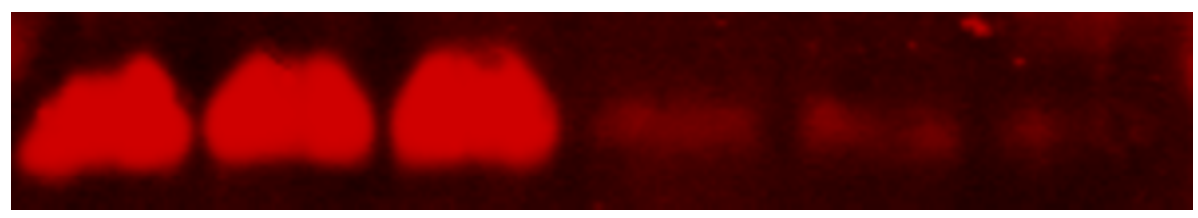

\section{GAPDH}

Figure 7 Western blotting analysis confirmation of representative protein in IBV-infected and mock-infected chicken embryo tissues.

cytoskeleton, calcium ion binding, the stress response, anti-oxidative stress, and macromolecular metabolism. Notably, some of the identified proteins have the ability to regulate apoptosis. Our study should facilitate a better understanding of the pathogenic mechanisms of IBV infection. Future work will focus on the analysis of the specific roles of some interesting proteins during IBV infection.

\section{Materials and methods}

\section{Experimental animals and virus infection}

Eighteen 13-day-old SPF chicken embryos (Harbin Veterinary Research Institute, China) were divided randomly into two groups, the IBV-infected group and the mock-infected group (nine chicken embryos in each group). Each chicken embryo in the IBV-infected group was inoculated with $100 \mu \mathrm{l}$ chorioallantoic fluid containing IBV $\mathrm{H}_{120}$ strain $\left(10^{5}-10^{6} \mathrm{EID}_{50}\right)$. As a control, each chicken embryo in the mock-infected group was inoculated in parallel with $100 \mu$ l sterile chorioallantoic fluid. The inoculated chicken embryos were incubated at $37^{\circ} \mathrm{C}$ and candled daily to check for embryonic viability.

Seventy-two hours after inoculation, the inoculated embryos were examined for characteristics of IBV infection. All the allantoic fluid was harvested from the IBVinfected and mock-infected chicken embryos to test for the presence of IBV using electron microscopy (EM), and for reverse transcriptase-polymerase chain reaction (RT-PCR) amplification of the majority of the $\mathrm{N}$ gene and parts of the 3'-UTR, as described previously [3,59]. Trachea and kidney tissues were removed quickly from the chicken embryos. Tissue samples from three randomly selected chicken embryos per group were pooled, and the pooled tissue samples were stored immediately at $-80^{\circ} \mathrm{C}$ for $2-\mathrm{DE}$ and real-time RT-PCR analysis. 


\section{Protein sample preparation}

The frozen tissues were rinsed in ice-cold PBS buffer, then placed in liquid nitrogen and ground thoroughly to a very fine powder. Tissue powder (100 mg) was dissolved in $500 \mu$ lysing solution containing $7 \mathrm{M}$ urea, 2 M thiourea, 4\% CHAPS, 40 mM DTT, 2\% IPG buffer $\mathrm{pH}$ 3-10 or $\mathrm{pH} 4-7,1 \%$ Nuclease Mix and 1\% Protease Inhibitor Mix (GE Healthcare), then incubated for $2 \mathrm{~h}$ at room temperature with vortexing once every $15 \mathrm{~min}$, and centrifuged at $15000 \times \mathrm{g}$ for $1 \mathrm{~h}$ at $4^{\circ} \mathrm{C}$. The supernatant was collected and purified with the PlusOne 2D Clean-up kit (GE Healthcare). The concentration of each protein sample was determined with the PlusOne 2D Quant Kit (GE Healthcare). Protein samples were aliquoted and stored at $-80^{\circ} \mathrm{C}$ for $2-\mathrm{DE}$ analysis.

\section{Two-dimensional electrophoresis}

Three independent sample pools of each kind of tissue per group were used for 2-DE analysis respectively. For tracheal tissue samples, $\mathrm{pH}$ 4-7 and linear pH 3-10 IPG strips were used. For kidney tissue samples, only linear pH 3-10 IPG strips were used. Briefly, $400 \mu \mathrm{g}$ protein (for $\mathrm{pH} 3-10$ strips) or $550 \mu \mathrm{g}$ (for $\mathrm{pH} 4-7$ strips) were added to the rehydration solution $(7 \mathrm{M}$ urea, $2 \mathrm{M}$ thiourea, $40 \mathrm{mM}$ DTT, $2 \%$ CHAPS, $0.5 \% \mathrm{pH} 3-10$ or pH 4-7 IPG buffer, and 0.002\% bromophenol blue) to make the final volume up to $250 \mu \mathrm{l}$, then loaded onto $13 \mathrm{~cm}, \mathrm{pH}$ 4-7 or linear pH 3-10 IPG strips (GE Healthcare). Isoelectric focusing (IEF) was performed on an Ettan IPGphor 3 (GE Healthcare) using the following procedure: $12 \mathrm{~h}$ at $30 \mathrm{~V}, 30 \mathrm{~min}$ at $200 \mathrm{~V}, 2 \mathrm{~h}$ at $500 \mathrm{~V}$, $1 \mathrm{~h}$ at $1000 \mathrm{~V}, 2 \mathrm{~h}$ of a linear gradient from $1000 \mathrm{~V}$ to $7000 \mathrm{~V}$, and $7000 \mathrm{~V}$ to $55000 \mathrm{Vh}$. After IEF, the IPG strips were first equilibrated with gentle shaking for 15 min in an equilibration buffer containing $6 \mathrm{M}$ urea, 50 $\mathrm{mM}$ Tris- $\mathrm{HCl}, \mathrm{pH} 8.8,30 \%$ glycerol, 2\% SDS, $0.002 \%$ bromophenol blue, and 1\% DTT, then for an additional 15 min in the same buffer except that the DTT was replaced by $2.5 \%$ iodoacetamide. For SDS-PAGE, the IPG strips were placed on $12.5 \%$ SDS-polyacrylamide gels, and electrophoresis was carried out using an SE600 Ruby system (GE Healthcare). The gels were stained with PlusOne Coomassie Blue R-350 (GE Healthcare) according to the manufacturer's protocol, and destained with $10 \%$ acetic acid solution.

\section{Image acquisition and analysis}

The stained 2-DE gels were scanned with an ImageScanner III (GE Healthcare). Spot detection, matching and quantification analyses were performed with Image Master 2D Platinum software v6.0 (GE Healthcare). For image analysis, three independent gels from the different sample pools for each group were compared. Protein spot intensity was defined as the normalized spot volume (vol \%), then the normalized volume values (vol $\%$ ) of individual protein spots were subjected to Student's $t$ test using SPSS statistical software package version 16.0. The criterion used to define differential expression of spots was that the ratio of the vol \% in the IBV-infected group vs. the mock-infected group was more than 1.5 ( $\mathrm{p}<0.05$ ) or less than 0.67 ( $\mathrm{p}<0.05)$. Differentially expressed protein spots were subjected to MS analysis.

\section{Protein identification by MALDI-TOF-TOF MS and MS/MS analysis}

The differentially expressed protein spots were excised manually from the gels, dehydrated in acetonitrile $(\mathrm{ACN})$, and dried at room temperature. Proteins were reduced with $10 \mathrm{mM}$ dithiothreitol (DTT) $/ 25 \mathrm{mM}$ $\mathrm{NH}_{4} \mathrm{HCO}_{3}$ at $56^{\circ} \mathrm{C}$ for $1 \mathrm{~h}$ and alkylated with $55 \mathrm{mM}$ iodoacetamide/ $25 \mathrm{mM} \mathrm{NH}_{4} \mathrm{HCO}_{3}$ in the dark at room temperature for $45 \mathrm{~min}$ in situ. Gel pieces were washed thoroughly with $25 \mathrm{mM} \mathrm{NH}_{4} \mathrm{HCO}_{3}, 50 \%$ and $100 \%$ $\mathrm{ACN}$, and dried in a Speedvac. Dried gel pieces were rehydrated with $2-3 \mu \mathrm{l}$ of trypsin (Promega) solution (10 $\mathrm{ng} / \mu \mathrm{l}$ in $25 \mathrm{mM}$ ammonium bicarbonate) at $4^{\circ} \mathrm{C}$ for 30 min. Excess liquid was discarded and the gel plugs were incubated at $37^{\circ} \mathrm{C}$ for $12 \mathrm{~h}$. Trifluoroacetic acid (TFA) was added to a final concentration of $0.1 \%$ to stop the digestive reaction.

The digests were spotted immediately onto $600 \mu \mathrm{m}$ Anchorchips (Bruker Daltonics). Spotting was achieved by pipetting $1 \mu \mathrm{l}$ of analyte onto the MALDI target plate in duplicate, then adding $0.05 \mu \mathrm{l}$ of $2 \mathrm{mg} / \mathrm{ml} \alpha$-cyano-4hydroxycinnamic acid in $0.1 \% \mathrm{TFA} / 33 \% \mathrm{ACN}$, which contained $2 \mathrm{mM}$ ammonium phosphate. Bruker peptide calibration mixture was spotted down for external calibration. All samples were allowed to air dry at room temperature, and $0.1 \%$ TFA was used for on-target washing. All samples were analyzed in the positive-ion, reflectron mode, on a TOF Ultraflex II mass spectrometer (Bruker Daltonics).

Each acquired mass spectrum (m/z range 700-4000, resolution 15 000-20 000) was processed using the Flex Analysis software version 2.4 (Bruker Daltonics) with the following settings: peak detection algorithm set at SNAP (Sort Neaten Assign and Place), S/N threshold at 3, and Quality Factor Threshold at 50. The trypsin autodigestion ion picks $(842.51,1045.56,2211.10$, and $2225.12 \mathrm{Da}$ ) were used as internal standards to validate the external calibration procedure. Matrix and/or autoproteolytic trypsin fragments, and known contaminants (e.g., keratins) were removed. The resulting peptide mass lists were used first to search the NCBInr database (release 16/01/2010, 10343571 sequences, 3528215794 residues) for Gallus sequences with MASCOT (v2.3) in the automated mode; the following parameters were 
used as criteria in the search: significant protein MOWSE score at $83(\mathrm{p}<0.05)$, minimum mass accuracy at $100 \mathrm{ppm}$, trypsin as enzyme, one missed cleavage site allowed, cysteine carbamidomethylation, acrylamide modified cysteine, methionine oxidation, and the minimum sequence coverage at $15 \%$. The samples identified by PMF were automatically submitted to MS/MS analysis. Three of the strongest peaks of the TOF spectra per sample were chosen for MS/MS analysis. For MS/MS spectra searching, the spectra were used to search the NCBInr database (release 16/01/2010, 10343571 sequences, 3528215794 residues) for Gallus sequences using MASCOT (v2.3). The search parameters for MS/ MS data included $100 \mathrm{ppm}$ for the precursor ion and $0.4 \mathrm{Da}$ for the fragment ions. Cleavage specificity and covalent modifications were considered as described above, and the score was higher than the minimal significant $(\mathrm{p}<0.05)$ individual ion score. All significant MS/ MS identifications by MASCOT were verified manually for spectral quality and matching of the $y$ and $b$ ion series.

\section{Real-time RT-PCR}

Specific primers were designed according to the corresponding gene sequences of MS-identified proteins using Beacon Designer software 7.5 (Primer Biosoft International). All the information on the primers is listed in Table 3. Total RNA was extracted using TRIzol Reagent (Invitrogen) according to the manufacturer's instructions. The concentration and purity of the RNA were measured using a spectrophotometer (GE Healthcare). Two micrograms of total RNA was reverse transcribed with $200 \mathrm{U}$ M-MLV Reverse Transcriptase (Invitrogen) and $500 \mathrm{ng}$ Oligo $(\mathrm{dT})_{18}$ as the first strand primer in $20 \mu \mathrm{l}$ reaction solution. Real-time PCR was carried out on the iCycler ${ }^{\circledR}$ real-time PCR detection system (Bio-Rad Laboratory). Each $25 \mu$ l reaction volume contained $1 \mu \mathrm{l} 10 \mu \mathrm{M}$ (each) forward and reverse primers, $12.5 \mu \mathrm{l} 2 \times$ SYBR $^{\circledR}$ Premix Ex Taq ${ }^{\mathrm{TM}}$ II (Takara), and $2 \mu \mathrm{l}$ 1:10 diluted cDNA products, and the final volume was adjusted using PCR-water. The following PCR program was used for amplification: $30 \mathrm{~s}$ at $95^{\circ} \mathrm{C}$, 40 cycles of denaturation at $95^{\circ} \mathrm{C}$ for $10 \mathrm{~s}$, and annealing and extension at $55^{\circ} \mathrm{C}$ for $30 \mathrm{~s}$. Three independent sample pools per group were analyzed. Quantitative analysis of the data was performed using the iCycler $\mathrm{IQ}^{5}$ optical system software version 2.0 (Bio-Rad Laboratory) in a Normalized Expression $(\Delta \Delta \mathrm{Ct})$ model, using the mockinfected group as calibrator (relative expression $=1$ ) and GAPDH as an internal reference gene.

\section{Western blotting analysis}

Samples from IBV-infected and mock-infected chicken embryo kidney tissues and tracheal tissues were lysed and protein concentrations were determined as described above. Equivalent amounts of total protein were subjected to $12 \%$ SDS-PAGE and then transferred to nitrocellulose membrane. After blocking for one hour at $37^{\circ} \mathrm{C}$, the membranes were incubated with mouse monoclonal antibody to annexin A5 (sc-32321, Santa Cruz Biotechnology, USA) and mouse monoclonal antibody to HSP27 (sc-51956, Santa Cruz Biotechnology, USA) for overnight at $4^{\circ} \mathrm{C}$. The membranes were then separately incubated with horseradish peroxidase (HRP)conjugated anti-mouse IgG (A2554, Sigma, USA) or IRDye700DX conjugated anti-mouse secondary antibody (610-130-121, Rockland, Gilbertsville, PA) for one hour at room temperature, finally visualized using 3,3-diaminobenzidine tetrahydrochloride (DAB) as the substrate or scanned on a LI-COR infrared imaging system using their Odyssey software (Li-Cor Bioscience, Lincoln, NE). HRP-conjugated monoclonal mouse anti-GAPDH (ab9482, Abcam, USA) was used as reference protein to check equal loading. Triplicates were performed.

Table 3 The primers used for real-time RT-PCR

\begin{tabular}{|c|c|c|c|c|}
\hline Gene symbol & Gene accession No. & Forward primer sequence $\left(5^{\prime}-3^{\prime}\right)$ & Reverse primer sequence $\left(5^{\prime}-3^{\prime}\right)$ & Amplicon size (bp) \\
\hline ANXA2 & NM_205351 & CTGTGATTGACTATGAACTGATTG & TTAACTTCCTTCTTGATGCTCTC & 196 \\
\hline ANXA5 & NM_001031538 & GGCTGGCACTGATGATGATACC & CCACCACAGAGGAGCAGGAG & 171 \\
\hline PRDX1 & XM_001233859 & CTGCTGGAGTGCGGATTG & AGAGGGTAGAAGAAGAACACAAC & 186 \\
\hline TPM1 & NM_205401 & CATTGCTGAAGAGGCTGAC & CGGACTTGGCTTTCTGATAG & 114 \\
\hline CALB1 & NM_205513 & AGGCAGGCTTGGACTTAAC & GCTGGCACCTAAAGAACAAC & 141 \\
\hline ENO1 & NM_205120 & AATGGATGGAACGGAGAAC & AGCAAGGTCAGCAATGTG & 127 \\
\hline ANXA1 & NM_206906 & GGACAACCAGGAGCAGGAATG & TGGCTTCATCTACACCCTITACAG & 134 \\
\hline HSPB1 & NM_205290 & CTGGTGGTGAAGACTAAGGATAAC & GGGTGTATTTGCGGGTGAAG & 106 \\
\hline MYLPF & M11030.1 & СCTCCAATGTCTTCTCTATG & TCCAACTCCTCGTTCTTC & 160 \\
\hline TRIM27.2 & NM_001099359 & GCAAGCACTGAAGGAAGAC & AGCCAGCAGGTGATGTTC & 166 \\
\hline EXFABP & NM_205422 & GCTGGACACGGACTACAAGAG & GCTCACCTCACGGCTTCTG & 106 \\
\hline GAPDH & AF047874 & GTGAAGGCTGCTGCTGATG & AGGTGGAGGAATGGCTGTC & 100 \\
\hline
\end{tabular}




\section{Additional material}

Additional file 1: Additional_file_1.doc containing the MALDI-TOF spectrum and MALDI-TOF-TOF spectrum of differentially expressed protein spots in IBV-infected chicken embryo tracheal tissues. Additional file 2: Additional_file_2.doc containing the PMF spectrum and Mascot database search results of differentially expressed protein spots in IBV-infected chicken embryo tracheal tissues.

Additional file 3: Additional_file_3.doc containing the MALDI-TOF spectrum and MALDI-TOF-TOF spectrum of differentially expressed protein spots in IBV-infected chicken embryo kidney tissues. Additional file 4: Additional_file_4.doc containing the PMF spectrum and Mascot database search results of differentially expressed protein spots in IBV-infected chicken embryo kidney tissues.

\section{Abbreviations \\ ACN: acetonitrile; CHAPS: 3-[(3-cholamidopropyl) dimethyl-ammonio] -1- propanesulfonate; DTT: dithiothreitol; GAPDH: glyceraldehyde-3-phosphate dehydrogenase; IBV: Infectious bronchitis coronavirus; IEF: isoelectric focusing; IPG: immobilized pH gradient; MALDI-TOF-TOF/MS: matrix-assisted laser desorption/ionization time-of-flight tandem mass spectrometry; PMF: peptide mass fingerprinting; RT-PCR: reverse transcriptase-polymerase chain reaction;SDS-PAGE: sodium dodecyl sulfate polyacrylamide gel electrophoresis; SPF: specific pathogen free; TFA: trifluoroacetic acid; 2-DE: two-dimensional gel electrophoresis.}

\section{Acknowledgements}

This work was funded by a grant from the National Key Technology R \& D Program of Ministry of Science and Technology of the P.R. China (No. 2006BAD06A03) and the earmarked fund for Modern Agro-industry Technology Research System.

\section{Authors' contributions}

SL designed the study. SL and ZC drafted the manuscript. ZC, ZH and YS carried out virus infection and test for the presence of IBV. ZC and HG carried out the 2-DE experiments, image analysis, excised the protein spots, data analysis and interpretation, and confirmed the differential expression by real-time RT-PCR and Western blotting analysis. SL wrote the manuscript. XK revised the manuscript. All authors read and approved the final manuscript.

\section{Competing interests}

The authors declare that they have no competing interests.

Received: 21 July 2010 Accepted: 8 March 2011

Published: 8 March 2011

\section{References}

1. Carstens E: Report from the 40th meeting of the Executive Committee of the International Committee of Taxonomy of Viruses. 2009, 1571-1574.

2. Cavanagh $D:$ Severe acute respiratory syndrome vaccine development: experiences of vaccination against avian infectious bronchitis coronavirus. Avian Pathol 2003, 32:567-582.

3. Liu S, Kong X: A new genotype of nephropathogenic infectious bronchitis virus circulating in vaccinated and non-vaccinated flocks in China. Avian Pathol 2004, 33:321-327.

4. Enjuanes L, Almazan F, Sola I, Zuniga S: Biochemical aspects of coronavirus replication and virus-host interaction. Annu Rev Microbiol 2006, 60:211-230.

5. Dar A, Munir S, Vishwanathan S, Manuja A, Griebel P, Tikoo S, Townsend H, Potter A, Kapur V, Babiuk LA: Transcriptional analysis of avian embryonic tissues following infection with avian infectious bronchitis virus. Virus Res 2005, 110:41-55.

6. Wang X, Rosa AJ, Oliverira HN, Rosa GJ, Guo X, Travnicek M, Girshick T: Transcriptome of local innate and adaptive immunity during early phase of infectious bronchitis viral infection. Viral Immunol 2006, 19:768-774.
7. Sun J, Jiang Y, Shi Z, Yan Y, Guo H, He F, Tu C: Proteomic alteration of PK15 cells after infection by classical swine fever virus. J Proteome Res 2008, 7:5263-5269.

8. Zheng X, Hong L, Shi L, Guo J, Sun Z, Zhou J: Proteomics analysis of host cells infected with infectious bursal disease virus. Mol Cell Proteomics 2008, 7:612-625.

9. Zhang X, Zhou J, Wu Y, Zheng X, Ma G, Wang Z, Jin Y, He J, Yan Y: Differential proteome analysis of host cells infected with porcine circovirus type 2. J Proteome Res 2009, 8:5111-5119.

10. Jiang XS, Tang LY, Dai J, Zhou H, Li SJ, Xia QC, Wu JR, Zeng R: Quantitative analysis of severe acute respiratory syndrome (SARS)-associated coronavirus-infected cells using proteomic approaches: implications for cellular responses to virus infection. Mol Cell Proteomics 2005, 4:902-913.

11. Thanthrige-Don N, Abdul-Careem MF, Shack LA, Burgess SC, Sharif S: Analyses of the spleen proteome of chickens infected with Marek's disease virus. Virology 2009, 390:356-367.

12. Bourchookarn A, Havanapan PO, Thongboonkerd V, Krittanai C: Proteomic analysis of altered proteins in lymphoid organ of yellow head virus infected Penaeus monodon. Biochim Biophys Acta 2008, 1784:504-511.

13. Emmott E, Wise H, Loucaides EM, Matthews DA, Digard P, Hiscox JA: Quantitative proteomics using SILAC coupled to LC-MS/MS reveals changes in the nucleolar proteome in influenza A virus-infected cells. Journal of proteome research 2010, 9:5335-5345.

14. Munday DC, Emmott E, Surtees R, Lardeau CH, Wu W, Duprex WP, Dove BK, Barr JN, Hiscox JA: Quantitative proteomic analysis of A549 cells infected with human respiratory syncytial virus. Molecular \& cellular proteomics: MCP 2010, 9:2438-2459

15. Coombs KM, Berard A, Xu W, Krokhin O, Meng X, Cortens JP, Kobasa D, Wilkins J, Brown EG: Quantitative proteomic analyses of influenza virusinfected cultured human lung cells. Journal of virology 2010, 84:10888-10906.

16. van Diepen A, Brand HK, Sama I, Lambooy LH, van den Heuvel LP, van der Well L, Huynen M, Osterhaus AD, Andeweg AC, Hermans PW: Quantitative proteome profiling of respiratory virus-infected lung epithelial cells. Journal of proteomics 2010, 73:1680-1693.

17. Emmott E, Rodgers MA, Macdonald A, McCrory S, Ajuh P, Hiscox JA: Quantitative proteomics using stable isotope labeling with amino acids in cell culture reveals changes in the cytoplasmic, nuclear, and nucleolar proteomes in Vero cells infected with the coronavirus infectious bronchitis virus. Mol Cell Proteomics 2010, 9:1920-1936.

18. Emmott E, Smith C, Emmett SR, Dove BK, Hiscox JA: Elucidation of the avian nucleolar proteome by quantitative proteomics using SILAC and changes in cells infected with the coronavirus infectious bronchitis virus. Proteomics 2010, 10:3558-3562.

19. Kong Q, Xue C, Ren X, Zhang C, Li L, Shu D, Bi Y, Cao Y: Proteomic analysis of purified coronavirus infectious bronchitis virus particles. Proteome Sci 2010, 8:29.

20. Liu S, Chen J, Kong X, Shao Y, Han Z, Feng L, Cai X, Gu S, Liu M: Isolation of avian infectious bronchitis coronavirus from domestic peafowl (Pavo cristatus) and teal (Anas). The Journal of general virology 2005, 86:719-725.

21. Wang CL, Coluccio LM: New insights into the regulation of the actin cytoskeleton by tropomyosin. Int Rev Cell Mol Biol 2010, 281:91-128.

22. Dantzig JA, Liu TY, Goldman YE: Functional studies of individual myosin molecules. Ann N Y Acad Sci 2006, 1080:1-18.

23. Liu N, Song W, Wang P, Lee K, Chan W, Chen H, Cai Z: Proteomics analysis of differential expression of cellular proteins in response to avian H9N2 virus infection in human cells. Proteomics 2008, 8:1851-1858.

24. Radtke K, Dohner K, Sodeik B: Viral interactions with the cytoskeleton: a hitchhiker's guide to the cell. Cell Microbiol 2006, 8:387-400.

25. Zhou Y, Frey TK, Yang JJ: Viral calciomics: interplays between $\mathrm{Ca}^{2+}$ and virus. Cell Calcium 2009, 46:1-17.

26. Christakos S, Liu Y: Biological actions and mechanism of action of calbindin in the process of apoptosis. J Steroid Biochem Mol Biol 2004, 89-90:401-404.

27. Bellido T, Huening M, Raval-Pandya M, Manolagas SC, Christakos S: Calbindin- $D_{28} \mathrm{k}$ is expressed in osteoblastic cells and suppresses their apoptosis by inhibiting caspase-3 activity. J Biol Chem 2000 275:26328-26332.

28. Gerke V, Moss SE: Annexins: from structure to function. Physiol Rev 2002, 82:331-371.

29. Ryzhova EV, Vos RM, Albright AV, Harrist AV, Harvey T, Gonzalez-Scarano F: Annexin 2: a novel human immunodeficiency virus type $1 \mathrm{Gag}$ binding 
protein involved in replication in monocyte-derived macrophages. J Virol 2006, 80:2694-2704.

30. Huang Y, Jin Y, Yan CH, Yu Y, Bai J, Chen F, Zhao YZ, Fu SB: Involvement of Annexin A2 in p53 induced apoptosis in lung cancer. Mol Cell Biochem 2008, 309:117-123.

31. Malhotra R, Ward M, Bright H, Priest R, Foster MR, Hurle M, Blair E, Bird M: Isolation and characterisation of potential respiratory syncytial virus receptor(s) on epithelial cells. Microbes Infect 2003, 5:123-133.

32. Fang YT, Lin CF, Liao PC, Kuo YM, Wang S, Yeh TM, Shieh CC, Su IJ, Lei HY, Lin YS: Annexin A2 on lung epithelial cell surface is recognized by severe acute respiratory syndrome-associated coronavirus spike domain 2 antibodies. Mol Immunol 2010, 47:1000-1009.

33. Derry MC, Sutherland MR, Restall CM, Waisman DM, Pryzdial EL: Annexin 2mediated enhancement of cytomegalovirus infection opposes inhibition by annexin 1 or annexin 5. J Gen Virol 2007, 88:19-27.

34. Huang RT, Lichtenberg B, Rick O: Involvement of annexin V in the entry of influenza viruses and role of phospholipids in infection. FEBS Lett 1996, 392:59-62

35. Solito E, Kamal A, Russo-Marie F, Buckingham JC, Marullo S, Perretti M: A novel calcium-dependent proapoptotic effect of annexin 1 on human neutrophils. FASEB J 2003, 17:1544-1546.

36. Narayan R, Gangadharan B, Hantz O, Antrobus R, Garcia A, Dwek RA, Zitzmann N: Proteomic analysis of HepaRG cells: a novel cell line that supports hepatitis B virus infection. J Proteome Res 2009, 8:118-122.

37. Hwang HJ, Moon CH, Kim HG, Kim JY, Lee JM, Park JW, Chung DK: Identification and functional analysis of salmon annexin 1 induced by a virus infection in a fish cell line. J Virol 2007, 81:13816-13824.

38. Samali A, Robertson JD, Peterson E, Manero F, van Zeijl L, Paul C, Cotgreave IA, Arrigo AP, Orrenius S: Hsp27 protects mitochondria of thermotolerant cells against apoptotic stimuli. Cell Stress Chaperones 2001, 6:49-58.

39. Ferns G, Shams S, Shafi S: Heat shock protein 27: its potential role in vascular disease. Int J Exp Pathol 2006, 87:253-274.

40. Kostenko S, Moens U: Heat shock protein 27 phosphorylation: kinases, phosphatases, functions and pathology. Cell Mol Life Sci 2009, 66:3289-3307.

41. Alfonso P, Rivera J, Hernaez B, Alonso C, Escribano JM: Identification of cellular proteins modified in response to African swine fever virus infection by proteomics. Proteomics 2004, 4:2037-2046.

42. Yokota S, Yokosawa N, Kubota T, Okabayashi T, Arata S, Fujii N: Suppression of thermotolerance in mumps virus-infected cells is caused by lack of HSP27 induction contributed by STAT-1. J Biol Chem 2003, 278:41654-41660.

43. Daly KA, Lefevre C, Nicholas K, Deane E, Williamson P: Characterization and expression of Peroxiredoxin 1 in the neonatal tammar wallaby (Macropus eugenii). Comp Biochem Physiol B Biochem Mol Biol 2008, 149:108-119.

44. Kim SY, Kim TJ, Lee KY: A novel function of peroxiredoxin 1 (Prx-1) in apoptosis signal-regulating kinase 1 (ASK1)-mediated signaling pathway. FEBS Lett 2008, 582:1913-1918.

45. Sun J, Shi Z, Guo H, Tu C: Changes in the porcine peripheral blood mononuclear cell proteome induced by infection with highly virulent classical swine fever virus. The Journal of general virology 2010, 91:2254-2262.

46. Pancholi V: Multifunctional alpha-enolase: its role in diseases. Cell Mol Life Sci 2001, 58:902-920

47. Wang HC, Leu JH, Kou GH, Wang AH, Lo CF: Protein expression profiling of the shrimp cellular response to white spot syndrome virus infection. Dev Comp Immunol 2007, 31:672-686.

48. Zhang H, Guo X, Ge X, Chen Y, Sun Q, Yang H: Changes in the cellular proteins of pulmonary alveolar macrophage infected with porcine reproductive and respiratory syndrome virus by proteomics analysis. J Proteome Res 2009, 8:3091-3097.

49. Modaressi S, Brechtel K, Christ B, Jungermann K: Human mitochondrial phosphoenolpyruvate carboxykinase 2 gene. Structure, chromosomal localization and tissue-specific expression. Biochem J 1998, 333(Pt 2):359-366.

50. Zhang L, Jia X, Zhang X, Sun J, Peng X, Qi T, Ma F, Yin L, Yao Y, Qiu C, Lu H: Proteomic analysis of PBMCs: characterization of potential HIVassociated proteins. Proteome Sci 2010, 8:12.
51. Munger J, Bajad SU, Coller HA, Shenk T, Rabinowitz JD: Dynamics of the cellular metabolome during human cytomegalovirus infection. PLOS Pathog 2006, 2:e132.

52. Cermelli S, Zerega B, Carlevaro M, Gentili C, Thorp B, Farquharson C, Cancedda R, Cancedda FD: Extracellular fatty acid binding protein (ExFABP) modulation by inflammatory agents: "physiological" acute phase response in endochondral bone formation. Eur J Cell Biol 2000, 79:155-164.

53. Descalzi Cancedda F, Dozin B, Zerega B, Cermelli S, Cancedda R: Extracellular fatty acid binding protein (Ex-FABP) is a stress protein expressed during chondrocyte and myoblast differentiation. Osteoarthritis Cartilage 2001, 9(Suppl A):S118-122.

54. Reymond A, Meroni G, Fantozzi A, Merla G, Cairo S, Luzi L, Riganelli D, Zanaria E, Messali $S$, Cainarca $S$, et al: The tripartite motif family identifies cell compartments. EMBO J 2001, 20:2140-2151.

55. Carthagena L, Bergamaschi A, Luna JM, David A, Uchil PD, MargottinGoguet F, Mothes W, Hazan U, Transy C, Pancino G, Nisole S: Human TRIM gene expression in response to interferons. PLoS One 2009, 4:e4894.

56. Kajaste-Rudnitski A, Pultrone C, Marzetta F, Ghezzi S, Coradin T, Vicenzi E: Restriction factors of retroviral replication: the example of Tripartite Motif (TRIM) protein 5a and 22. Amino Acids 2010, 39:1-9.

57. Ridolfi B, Catone S, Sgarbanti M, Sernicola L, Battistini A, Parolin C, Titti F, Borsetti A: Generation of a human immunodeficiency virus type 1 chronically infected monkey B cell line expressing low levels of endogenous TRIM5a. J Cell Physiol 2009, 221:760-765.

58. Shiina T, Briles WE, Goto RM, Hosomichi K, Yanagiya K, Shimizu S, Inoko H, Miller MM: Extended gene map reveals tripartite motif, C-type lectin, and Ig superfamily type genes within a subregion of the chicken MHC-B affecting infectious disease. J Immunol 2007, 178:7162-7172.

59. Liu S, Chen J, Han Z, Zhang Q, Shao Y, Kong X, Tong G: Infectious bronchitis virus: $S 1$ gene characteristics of vaccines used in China and efficacy of vaccination against heterologous strains from China. Avian Pathol 2006, 35:394-399.

doi:10.1186/1477-5956-9-11

Cite this article as: Cao et al:: Proteomic analysis of chicken embryonic trachea and kidney tissues after infection in ovo by avian infectious bronchitis coronavirus. Proteome Science 2011 9:11.

\section{Submit your next manuscript to BioMed Central and take full advantage of:}

- Convenient online submission

- Thorough peer review

- No space constraints or color figure charges

- Immediate publication on acceptance

- Inclusion in PubMed, CAS, Scopus and Google Scholar

- Research which is freely available for redistribution

Submit your manuscript at www.biomedcentral.com/submit
Ciomed Central 